\title{
ADSORPCJA DWUWARTOŚCIOWYCH KATIONÓW NA GRANICY FAZ HYDROKSYAPATYT/ROZTWÓR ELEKTROLITU
}

\author{
ADSORPTION OF DIVALENT CATIONS \\ AT THE HYDROXYAPATITE/ELECTROLYTE \\ SOLUTION INTERFACE
}

\section{Wladysław Janusz*, Ewa Skwarek}

Uniwersytet Marii Curie-Skłodowskiej, Wydział Chemii,

Ul. M. Curie-Skłodowskiej 3, 20-031 Lublin

*e-mail: wladyslaw.janusz@poczta.umcs.lublin.pl

Abstract

Wykaz stosowanych skrótów

Wprowadzenie

1. Miejsca aktywne na powierzchni hydroksyapatytu

2. Materiał i metodyka pomiarów

2.1. Metodyka pomiarów

3. Wyniki i dyskusja wyników

3.1. Kinetyka adsorbcji dwuwartościowych kationów metali na hydroksyapatycie

3.2. Adsorbcja kationów dwuwartościowych na hydroksyapatycie w funkcji $\mathrm{pH}$

3.3. Wpływ adsorpcji kationów dwuwartościowych na hydroskyapatycie na potencjał dzeta

3.4. Wpływ adsoprcji kationów dwuwartościowych na hydroskyapatycie na rozkład ziarnowy cząstek hydroksyapatytu

3.5. Wpływ adsorpcji kationów dwuwartościowych na hydroskyapatycie na strukturę krystaliczną hydroksyapatytu i jego krystaliczność

Uwagi końcowe

Piśmiennictwo cytowane 
Prof. dr hab. Wladysław Janusz ukończył studia na Wydziale Matematyki, Fizyki i Chemii Uniwersytetu Marii Curie-Skłodowskiej w Lublinie w1974 r. uzyskując tytuł zawodowy magistra chemii. Stopień doktora nauk chemicznych otrzymał w 1981r na Wydziale Matematyki, Fizyki i Chemii UMCS, a doktora habilitowanego nauk chemicznych w 2001 na Wydziale Chemii UMCS. W roku 2007 otrzymał tytuł naukowy profesora nauk chemicznych. Pracę zawodową podjął w Pracowni Radiochemii i Zastosowań Radioizotopów w 1973r. Po przekształceniu Pracowni w Zakład Radiochemii i Chemii Koloidów kontynuował pracę w nowej jednostce do roku 2019, a od roku 2019 do 2020 pracował w Katedrze Radiochemii i Chemii Środowiska, która powstała po połączeniu Zakładu Radiochemii i Chemii Koloidów i Zakładu Chemii Środowiskowej. Od 2020r. emerytowany profesor na Wydziale Chemii UMCS. Zainteresowania naukowe dotyczą struktury podwójnej warstwy elektrycznej i adsorpcji jonów na granicy faz w układach dyspersyjnych ciało stałe/wodne roztwory elektrolitów.

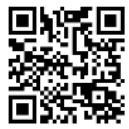

iD https://orcid.org/0000-0001-6590-0956

Dr hab. Ewa Skwarek prof. uczelni jest pracownikiem naukowo-dydaktycznym Instytutu Nauk Chemicznych na Uniwersytecie Marii Curie-Skłodowskiej w Lublinie. Stopień magistra uzyskała w 1996 r., doktora - w 2005 r., doktora habilitowanego - w 2018 r. Obszar jej zainteresowań badawczych obejmuje procesy: synteza i charakterystykę fizykochemiczną tlenków metali, fosforanów metali, hydroksyapatytu jego modyfikacji i kompozytów; badania procesu adsorpcji związków organicznych i nieorganicznych na granicy faz ciało stałe/roztwór $\mathrm{z}$ wykorzystaniem metod radioizotopowych; fizykochemiczne badania układów koloidalnych nierozpuszczalnych tlenków, węglanów, fosforanów i krzemianów metali. Jej dorobek naukowy obejmuje 72 artykułów z bazy Journal Citation Reports znajdujących się na aktualnie obowiązującej liście MNiSW, 9 innych artykułów oraz 10 rozdziałów w książkach i monografiach. Jej prace były cytowane 1137 razy, a indeks h wynosi 17. Brała udział w realizacji grantów krajowych międzynarodowych, jako wykonawca. 


\begin{abstract}
Functional and composite materials obtained from hydroxyapatite (HAp) are widely used in practice, which results in intensive research of systems containing hydroxyapatite. Doping with divalent ions of hydroxyapatite changes its properties, thus extending its application in material science. Substitution of calcium ions in the surface layer of hydroxyapatite by metal cations is used in the development of new catalysts, sorbents, sensors and materials for other applications. The doping of the surface of the hydroxyapatite with divalent ions may occur as a result of adsorption of metal cations on the surface groups and calcium exchange in the crystal structure of the hydroxyapatite. The paper presents the mechanisms of adsorption of selected bivalent ions $\mathrm{Ba}^{2+}, \mathrm{Cd}^{2+}, \mathrm{Co}^{2+}, \mathrm{Fe}^{2+}, \mathrm{Sr}^{2+}, \mathrm{Zn}^{2+}$ on hydroxyapatite. The influence of cation adsorption on unit cell parameters, crystallite size and particle size distribution is discussed.
\end{abstract}

Keywords: hydroxyapatite, adsorption of divalent cations

Słowa kluczowe: hydroksyapatyt, adsorpcja kationów dwuwartościowych 


\section{WYKAZ STOSOWANYCH SKRÓTÓW}

$0.8 \%$ CHAp_A

1\% CHAp_B

$\mathrm{a}_{\mathrm{e}}$

$\mathrm{A}_{0}$

$\mathrm{n}$

$\mathrm{A}_{\mathrm{i}}$

BET

BJH

CI

CR2

$\mathrm{D}_{(002)}$

$\mathrm{D}_{(300)}$

E

FWHM

HAp

LREE

$\mathrm{M}^{2+}$

$\mathrm{MOH}^{+}$

$\mathrm{M}(\mathrm{OH})_{2}$

$\mathrm{M}(\mathrm{OH})_{3}$

PDF

$\mathrm{pK}$

$\mathrm{S}_{\mathrm{w}}$

$\mathrm{A}_{\max }$

$\mathrm{R}_{\mathrm{wp}}$

Sig

SSE

$\mathrm{X}_{\mathrm{C}}$

XRD

XRF
- hydroksyapatyt węglanowy typu A o zawartości 0,8\%

$\mathrm{CO}_{3}$

- hydroksyapatyt węglanowy typu $\mathrm{B}$ o zawartości $1 \% \mathrm{CO}_{3}$

- adsorpcja równowagowa

- względna adsorpcja równowagowa

- liczba wyrazów równania multi-eksponencjalnego kinetyki adsorpcji

- udział „,i”-tego procesu w adsorpcji charakteryzowanego przez stałą k szybkości $\mathrm{k}_{\mathrm{i}}$.

- metoda Brunauera, Emmetta, Tellera

- metoda Barreta, Joynera, Halenda

- indeks krystaliczności

- drugi punkt odwrócenia ładunku

- wielkość krystalitu dla płaszczyzny kryształu 002

- wielkość krystalitu dla płaszczyzny kryształu 300

- elektroujemność

- szerokość piku w połowie jego wysokości

- hydroskyapatyt

- lekkie pierwiastki ziem rzadkich

- kation dwuwartościowy metalu

- kation $\mathrm{M}^{2+}$ koordynowany przez jeden jon $\mathrm{OH}^{-}$

- kation $\mathrm{M}^{2+}$ koordynowany przez dwa jony $\mathrm{OH}^{-}$

- kation $\mathrm{M}^{2+}$ koordynowany przez trzy jony $\mathrm{OH}^{-}$

- proszkowe dane dyfrakcyjne

- ujemny logarytm stałej równowagi

- powierzchnia właściwa próbki

- adsorpcja maksymalna kationu

- weighted residual-Maud software-ważona reszta

- dobroć dopasowania, parametr w programie Maud

- suma kwadratów różnicy gęstości adsorpcji obliczonej

i gęstości adsorpcji eksperymentalnej

- Crystallity degree - stopień krystaliczności

- dyfrakcja promieniowania rentgenowskiego,

- rentgenowska analiza fluorescencyjna 


\section{WPROWADZENIE}

Materiały funkcjonalne i kompozytowe otrzymywane $\mathrm{z}$ hydroksyapatytu (HAp) znajdują szerokie zastosowanie w praktyce, co wiąże się z intensywnymi badaniami układów zawierających hydroksyapatyt. Oprócz stosowanych technologii, ciągle prowadzone są badania nad nowymi zastosowaniami hydroksyapatytu, z których najwięcej dotyczy biomateriałów [1-5]. Ponadto podejmowane badania dotyczą użycia hydroksyapatytu jako adsorbentu [6, 7], katalizatora[8], czujnika[9,10], nośnika leków [11,12], odczynników do diagnostyki medycznej i terapii hipotermicznej nowotworów [13]. Otrzymanie hydroksyapatytu o pożądanych właściwościach $\mathrm{w}$ celu praktycznych zastosowań uzyskuje się w wyniku: funkcjonalizacji powierzchni hydroskyapatytu, podstawieniu jonów w strukturze krystalicznej hydroksyapatytu lub/i pokryciu powierzchni nanocząstkami $[1,3]$.

Jony wapnia w sieci krystalicznej HAp mogą zostać zastąpione/podstawione innymi kationami, a aniony fosforanowe innymi anionami np. $\mathrm{Cl}^{-}, \mathrm{F}^{-}, \mathrm{SO}_{4}{ }^{2-}, \mathrm{CO}_{3}{ }^{2-}$ [3]. Zastąpienie mniej niż $20 \%$ jonów $\mathrm{Ca}^{2+}$ małymi jonami $\left(\mathrm{Zn}^{2+}, \mathrm{Mn}^{2+}, \mathrm{Cd}^{2+}\right.$, $\mathrm{Mg}^{2+}$ ) nieznacznie zmniejsza parametry sieci krystalicznej i stopień krystaliczności. Podmiana jonami większymi od jonów $\mathrm{Ca}^{2+}$ przy niskim stężeniu prowadzi do wzrostu parametrów komórki. Wysokie stężenie jonów, np. Zn, Pb, w związku ze wzrostem rozpuszczalności hydroksyapatytu, przyczyniają się do powstania nowej fazy fosforanów metali. Zmiana parametrów sieci krystalicznej hydroksyapatytu może powodować zmiany: krystaliczności, stabilności termicznej, morfologii, rozpuszczalności oraz zmiany właściwości fizykochemicznych i biologicznych [14].

Syntezę nanocząstek HAp domieszkowanych jonami metali zwykle prowadzi się metodami współstrącenia lub adsorpcji i/lub wymiany jonów. Pierwsza z metod polega na wprowadzeniu do roztworu, przed wytrąceniem HAp, jonów $\mathrm{Ca}^{2+}$, jonów metali np.: $\mathrm{Ag}+, \mathrm{Zn}^{2+}, \mathrm{Ni}^{2+}, \mathrm{Fe}^{2+}, \mathrm{Pb}^{2+}$, lekkich pierwiastków ziem rzadkich (LREE: $\mathrm{La}^{3+}, \mathrm{Ce}^{3+}, \mathrm{Pr}^{3+}, \mathrm{Nd}^{3+}$ and $\mathrm{Sm}^{3+}$ ) [15-21]. Druga metoda polega na dodaniu jonów metalu do zawiesiny HAp, metodą tą domieszkowano HAp następującymi jonami: $\mathrm{Ni}^{2+}, \mathrm{Pb}^{2+}, \mathrm{Fe}^{2+}, \mathrm{Mn}^{2+}, \mathrm{Zn}^{2+}, \mathrm{Ni}^{2+}, \mathrm{Cu}^{2+}, \mathrm{Co}^{2+}, \mathrm{Cr}^{3+}$ lub $\mathrm{Al}^{3+}$ [14,22-25]. Metoda wytrącania zapewnia ciągły rozkład stężenia jonów metali od fazy objętościowej do powierzchniowej, podczas gdy metoda wymiany jonowej powoduje zwykle wyższe stężenie jonów metali na powierzchni cząstek HAp, niż w głębi fazy objętościowej, ponieważ wymiana jonowa $\mathrm{w}$ pierwszym etapie zachodzi $\mathrm{w}$ warstwie powierzchniowej cząstek, a później wyniku dyfuzji jony przenikają do części objętościowej [26]. 
Domieszkowanie hydroksyapatytu jonami dwuwartościowymi zmienia jego właściwości, tym samym rozszerza jego zastosowanie w inżynierii materiałowej. Podstawienie jonów wapnia w powierzchniowej warstwie hydroksyapatytu przez kationy metali jest stosowane w opracowywaniu nowych katalizatorów, sorbentów, czujników i materiałów do innych zastosowań o nowych właściwościach[27], np. domieszkowanie jonami $\mathrm{Cu}^{2+}, \mathrm{Ni}^{2+}, \mathrm{Co}^{2+}$ powierzchni HAp wpływa na właściwości katalityczne[8].

\section{MIEJSCA AKTYWNE NA POWIERZCHNI HYDROSKYAPATYTU}

Domieszkowanie jonami dwuwartościowymi powierzchni hydoksyapatytu może zachodzić w wyniku wymiany jonów z jonami wapnia z sieci krystalicznej $[28,29]$

$$
\mathrm{Ca}_{10}\left(\mathrm{PO}_{4}\right)_{3}(\mathrm{OH})_{2}+\mathrm{xM}^{2+} \rightarrow \mathrm{M}_{\mathrm{x}} \mathrm{Ca}(10-\mathrm{x})\left(\mathrm{PO}_{4}\right)_{3}(\mathrm{OH})_{2}+\mathrm{xCa}^{2+}
$$

Drugim mechanizmem domieszkowania jonami dwuwartościowymi hydoksyapatytu jest adsorpcja kationów metali na grupach powierzchniowych:

Adsorpcja kationów na grupie wodorofosforanowej [30-32]:

$$
\begin{gathered}
\mathrm{HAp}-\mathrm{POH}+\mathrm{M}^{2+} \leftrightarrow \text { HAp-PO-M }{ }^{+}+\mathrm{H}^{+} \\
2 \mathrm{HAP}-\mathrm{POH}+\mathrm{M}^{2+} \rightarrow(\text { HAp-PO })_{2} \mathrm{M}^{2+}+2 \mathrm{H}^{+}
\end{gathered}
$$

Adsorpcja kationów na grupach hydroksylowych hydroksyapatytu [33]:

$$
\begin{gathered}
\mathrm{HAp}-\mathrm{OH}+\mathrm{M}^{2+} \leftrightarrow \mathrm{HAp}-\mathrm{O}-\mathrm{M}^{+}+\mathrm{H}^{+} \\
2 \mathrm{HAP}-\mathrm{OH}+\mathrm{M}^{2+} \rightarrow\left(\mathrm{HAp}-\mathrm{O}^{-}\right)_{2} \mathrm{M}^{2+}+2 \mathrm{H}^{+}
\end{gathered}
$$

Określone metodą radioizotopową i obliczone ma podstawie danych krystalograficznych stężenie jonów $\mathrm{Ca}^{2+}$ na powierzchni wyniosło 4,5 jonów $/ \mathrm{nm}^{2}$, zaś stężenie jonów $\mathrm{PO}_{4}{ }^{3-}$ wyniosło 3,02 jonów/nm ${ }^{2}$ [34]. Stężenie grup -OH obliczone na podstawie danych krystalograficznych wynosiło 2,5 grup -OH/nm ${ }^{2}$ [35], natomiast na postawie analizy widm IR stężenie tych grup określono na $1,0 \pm 0,4$ grup $-\mathrm{OH} / \mathrm{nm}^{2}[36]$.

$\mathrm{W}$ procesie wymiany kationów metali $\mathrm{z}$ wapniem na powierzchni hydroksyapatytu rozważa się dwie właściwości jonów: promień jonowy i elektroujemność. Saleeb i de Bruyn sformułowali dwa następujące warunki, którymi powinny charakteryzować się kationy wymieniające wapń $\mathrm{w}$ sieci krystalicznej hydroskyapatytu [37]:

1. Promień wymienianego kationu nie powinien różnić się od promienia $\mathrm{Ca}^{2+}$ o więcej niż 15\%, więc jego zastąpienie w strukturze sieciowej HAp nie spowoduje znaczącej deformacji sieci krystalicznej. Suzuki i współpr. wyznaczyli zakres promienia wymienianych jonów od 0,09 do $0,13 \mathrm{~nm}[38]$.

2. Wysoka elektroujemność, do 2,4, sprzyja zastępowaniu jonów. 
$\mathrm{Na}$ Rysunku 1 porównano elektroujemność i promień jonowy wapnia zelektroujemnością i promieniem jonowym kationów zdolnych do jego podstawienia $\mathrm{w}$ strukturze hydroskyapatytu. Na rysunku tym szarym prostokątem zaznaczono obszar, który według Suzuki i współpr. dopuszcza wymianę jonów w sieci krystalicznej hydroksyapatytu[38]. Jednak w późniejszych badaniach okazało się, że jony o promieniach poza zaznaczonym na Rys.1 zakresem mogą również wymieniać wapń w sieci HAp[39].

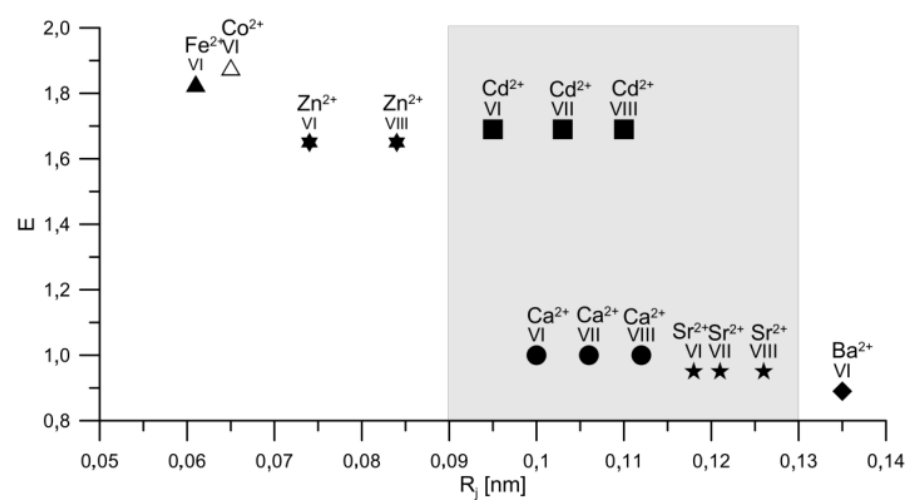

Rysunek 1. Porównanie promieni jonowych $\left(R_{j}\right)$ i elektroujemności (E) wybranych kationów stosowanych do podstawienia jonów wapnia w hydroksyapatycie. Cyfry rzymskie pod symbolem jonu oznaczają liczbę koordynacyjną jonu

Figure 1. Comparison of ion radius $\left(R_{j}\right)$ and electronegativity (E) of selected cations used for the substitution of calcium ions in hydroxyapatite. The Roman numerals below the ion symbol indicate the coordination number of the ion

Oprócz wymiany jonowej kationów metali z jonami wapnia z HAp i adsorpcji jonów na powierzchniowych grupach funkcyjnych HAp w literaturze opisywany jest trzeci proces, który powoduje wychwyt kationów metalu z roztworu przez hydroskyapatyt. Proces ten wiąże się $\mathrm{z}$ rozpuszczeniem hydroksyapatytu, a następnie wytrąceniem nowej fazy stałej. Zachodzi on przy wysokim początkowym stężeniu dwuwartościowego kationu metalu większym niż $1 \mathrm{mmol} / \mathrm{dm}^{3}$ i kwaśnym $\mathrm{pH}$ roztworu według następujących reakcji[31]:

$$
\begin{gathered}
\mathrm{xM}^{2+}+(5-\mathrm{x}) \mathrm{Ca}^{2+}+3 \mathrm{H}_{2} \mathrm{PO}_{4}^{-} \leftrightarrow\left(\mathrm{M}_{\mathrm{x}} \mathrm{Ca}_{5-\mathrm{x}}\right)\left(\mathrm{PO}_{4}\right)_{3} \mathrm{OH}+7 \mathrm{H}^{+} \\
\mathrm{xM}^{2+}+(5-\mathrm{x}) \mathrm{Ca}^{2+}+3 \mathrm{HPO}_{4}^{2-}+2 \mathrm{H}_{2} \mathrm{O} \leftrightarrow\left(\mathrm{M}_{\mathrm{x}} \mathrm{Ca}_{5-\mathrm{x}}\right)\left(\mathrm{PO}_{4}\right)_{3} \mathrm{OH}+4 \mathrm{H}^{+}
\end{gathered}
$$

$\mathrm{Na}$ Rys 2 przedstawiono diagram rozpuszczalności hydroskyapatytu, który skonstruowano biorąc pod uwagę następujące wartości: iloczyn rozpuszczalności hydroksyapatytu $\mathrm{pK}_{\mathrm{s} 0}\left(\mathrm{Ca}_{5}\left(\mathrm{PO}_{4}\right)_{3} \mathrm{OH}\right)=57,43 \quad[40]$, stałe dysocjacji kwasu fosforowego: $\mathrm{pK}_{\mathrm{a} 1}=2,16, \quad \mathrm{pK}_{\mathrm{a} 2}=7,21, \quad \mathrm{pK}_{\mathrm{a} 3}=12,32$ [41], $\mathrm{i}$ stałe stabilności kompleksów fosforanu wapnia $\mathrm{pK}\left(\mathrm{CaH}_{2} \mathrm{PO}_{4}{ }^{+}\right)=-0,84, \mathrm{pK}\left(\mathrm{CaHPO}_{4}\right)=-2,55$ oraz $\mathrm{pK}\left(\mathrm{CaPO}_{4}{ }^{-}\right)=5,54$ [42]. Diagram rozpuszczalności hydroksyapatytu w funkcji $\mathrm{pH}$ wskazuje, że minimalna rozpuszczalność hydroksyapatytu występuje przy pH $\sim 12$. 
Badany zakres adsorpcji jonów metalu $\mathrm{w}$ funkcji $\mathrm{pH}$ jest ograniczony ze względu na rozpuszczalność hydroskyapatytu do $\mathrm{pH}$ od $\sim 6$ do $\mathrm{pH} \sim 11$. W tym zakresie $\mathrm{pH}$, rozpuszczalność hydroksyapatytu zmienia się istotnie, a stężenie jonów wapnia i fosforanu zmniejsza się około dziewięćset razy.

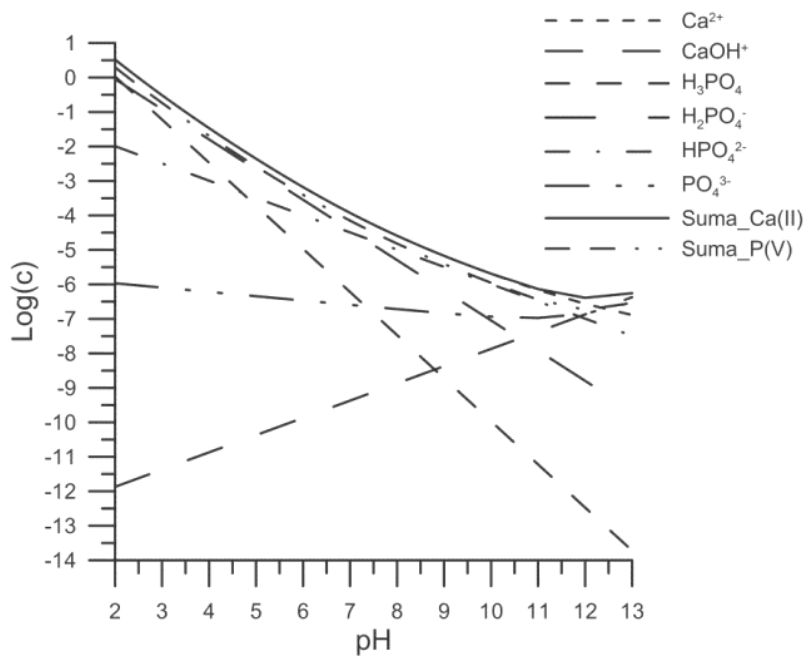

Rysunek 2. Diagram rozpuszczalności hydroksyapatytu

Figure 2. Hydroxyapatite solubility diagram

Wysoka rozpuszczalność hydroksyapatytu przy wysokim stężeniu adsorbowanego kationu, powyżej $1 \mathrm{mmol} / \mathrm{dm}^{3}$ może powodować wytrącanie nowej fazy w wyniku reakcji kationów metali z jonami fosforanowymi[30].

W Tabeli 1 przedstawiono mechanizmy adsorpcji wybranych dwuwartościowych kationów metali na hydroksyapatycie. Jak widać ubytek jonów $\mathrm{z}$ roztworu wybranego jonu $\mathrm{np}$. $\mathrm{Zn}^{2+}$ może być thumaczony jednym mechanizmem, a w innych pracach dwoma lub trzema.

Tabela 1. Mechanizmy adsorpcji dwuwartościowych kationów metali na hydroksyapatycie

Table 1. Mechanisms of adsorption of divalent metal cations on hydroxyapatite

\begin{tabular}{|l|l|l|l|l|}
\hline Kation & Adsorpcja & Wymiana $\mathrm{z} \mathrm{Ca}^{2+}$ & Wytrącanie & Literatura \\
\hline $\mathrm{Cd}^{2+}$ & $\mathrm{x}$ & & & {$[43]$} \\
\hline $\mathrm{Zn}^{2+}$ & $\mathrm{x}$ & & & {$[31]$} \\
\hline $\mathrm{Zn}^{2+}, \mathrm{Cd}^{2+}$ & $\mathrm{x}$ & & $\mathrm{x}$ & {$[30]$} \\
\hline $\mathrm{Ag}^{+}, \mathrm{Cu}^{2+}, \mathrm{Zn}^{2+}$ & & $\mathrm{x}$ & $\mathrm{x}$ & {$[44]$} \\
\hline $\mathrm{Ni}^{2+}, \mathrm{Cu}^{2+}, \mathrm{Co}^{2+}$, & $\mathrm{x}$ & $\mathrm{x}$ & & {$[22]$} \\
\hline $\mathrm{Zn}^{2+}, \mathrm{Cd}^{2+}, \mathrm{Pb}^{2+} \mathrm{C}_{\mathrm{M}}>0,01 \mathrm{M}$ & & & $\mathrm{x}$ & {$[45]$} \\
\hline $\mathrm{Co}^{2+}$ & $\mathrm{x}$ & $\mathrm{x}$ & & {$[46]$} \\
\hline $\mathrm{Sr}^{2+}$ & & $\mathrm{x}$ & & {$[47]$} \\
\hline $\mathrm{Ba}^{2+}$ & $\mathrm{x}$ & $\mathrm{x}$ & $\mathrm{x}$ & {$[48]$} \\
\hline $\mathrm{Pb}^{2+}, \mathrm{Cd}^{2+}, \mathrm{Zn}^{2+}, \mathrm{Sr}^{2+}$ & & $\mathrm{x}$ & $\mathrm{x}$ & {$[49]$} \\
\hline
\end{tabular}




\begin{tabular}{|l|l|l|l|l|}
\hline $\mathrm{Pb}^{2+}$ & & & $\mathrm{x}$ & {$[50]$} \\
\hline $\mathrm{Pb}^{2+}$ & & $\mathrm{x}$ & & {$[51]$} \\
\hline $\mathrm{Pb}^{2+}$ & & $\mathrm{x}$ & & {$[52]$} \\
\hline $\mathrm{Pb}^{2+}$ & & $\mathrm{x}$ & & {$[53]$} \\
\hline
\end{tabular}

\section{MATERIAŁ I METODYKA POMIARÓW}

Badania adsorpcji wybranych kationów dwuwartościowych, tj. $\mathrm{Ba}^{2+}, \mathrm{Cd}^{2+}$, $\mathrm{Co}^{2+}, \mathrm{Fe}^{2+}, \mathrm{Sr}^{2+}, \mathrm{Zn}^{2+}$, prowadzono na jednej $\mathrm{z}$ trzech próbek otrzymanych metodami mokrymi lub próbce komercyjnej. Próbkę oznaczoną jako HAp_S1 otrzymano zgodnie $\mathrm{z}$ metodą zaproponowaną przez Akao i wsp. [54], próbkę oznaczoną HAp_S2 otrzymano zgodnie z metodą zaproponowaną przez Vysotskaya i wsp. [55], natomiast próbkę oznaczoną jako HAp_S3 otrzymano zgodnie z metodą opisaną przez Mostafę [56]. Próbkę oznaczoną Hap_K zakupiono od Aldrich. Charakterystykę powierzchni badanych próbek hydroksyapatytu uzyskaną na podstawie izoterm adsorpcji/desorpcji azotu zamieszczono w Tabeli 2.

Tabela 2. Charakterystyka powierzchni badanych próbek hydroskyapatytu

Table 2. Surface characteristics of the studied hydroskyapatite samples

\begin{tabular}{|l|l|l|l|l|}
\hline Właściwość & HAp_S1 & HAp_S2 & HAp_S3 & HAp_K \\
\hline Pole powierzchni z izotermy BET $\left[\mathrm{m}^{2} / \mathrm{g}\right]$ & 158,4 & 52,44 & 104,79 & 100,64 \\
\hline Pole powierzchni z izotermy Langmuira [m/g] & 217,86 & 67,27 & 134,3 & 147,23 \\
\hline $\begin{array}{l}\text { Sumaryczna objętość porów z adsorpcji, metoda BJH } \\
{\left[\mathrm{cm}^{3} / \mathrm{g}\right]}\end{array}$ & 0,69 & 0,18 & 0,54 & 0,463 \\
$\begin{array}{l}\text { Sumaryczna objętość porów z desorpcji obliczona } \\
\text { metoda BJH [cm } / \mathrm{g}]\end{array}$ & 0,68 & 0,24 & 0,53 & 0,457 \\
\hline Średni promień porów z metody BET [nm] & 17,03 & 13,36 & 17,72 & 18,5 \\
\hline Sredni promień porów z adsorpcji-metoda BJH [nm] & 15,30 & 15,59 & 18,08 & 18,8 \\
\hline Średni promień porów z desorpcji -metoda BJH [nm] & 14,03 & 14,97 & 17,46 & 15,6 \\
\hline Adsorpcja kationów & $\mathrm{Sr}^{2+}, \mathrm{Co}^{2+}$ & $\mathrm{Cd}^{2+}$ & $\mathrm{Zn}^{2+}$ & $\mathrm{Ba}^{2+} \mathrm{Fe}^{2+}$ \\
\hline
\end{tabular}

\subsection{METODYKA POMIARÓW}

Badania sorpcji jonów dwuwartościowych $\mathrm{Ba}^{2+}, \mathrm{Sr}^{2+}, \mathrm{Co}^{2+}, \mathrm{Cd}^{2+} \mathrm{i} \mathrm{Zn}^{2+}$ prowadzono metodą ubytku radioaktywności z roztworu, odpowiednio przy użyciu radioizotopów: ${ }^{133} \mathrm{Ba}^{2+},{ }^{90} \mathrm{Sr}^{2+},{ }^{60} \mathrm{Co}^{2+},{ }^{109} \mathrm{Cd}^{2+} \mathrm{i}^{65} \mathrm{Zn}^{2+}$. W przypadku pomiarów adsorpcji jonów $\mathrm{Sr}^{2+}$, w oparciu pomiar radioaktywności ${ }^{90} \mathrm{Sr}^{2+}$, pomiar prowadzono w dwóch kanałach licznika w celu oddzielenia radioaktywności pochodzącej od ${ }^{90} \mathrm{Y}^{3+}$ (który jest w równowadze wiekowej $\mathrm{z}^{90} \mathrm{Sr}^{2+}$ ). Szczegóły pomiarów adsorpcji jonów zamieszczono w pracach:[43,45-48]. Adsorpcję jonów $\mathrm{Fe}^{2+}$ na hydroksyapatycie mierzono również metodą ubytku stężenia jonów $\mathrm{Fe}^{2+}$, ale ich stężenie w roztworze oznaczano metodą XRF. W celu uniknięcia utleniania jonów $\mathrm{Fe}^{2+}$, adsorpcję z roztworów prowadzono w obecności hydroksyloaminy. 
Rozkład wielkości cząstek HAp wyznaczono metodą dyfrakcji laserowej za pomocą aparatu Mastersizer 2000 firmy Malvern.

Potencjał dzeta hydroskyapatytu mierzono metoda elektroforezy przy użyciu aparatów Zetasizer NS (adsorpcja jonów $\mathrm{Ba}^{2+}$ ) lub Zetasizer 3000 (adsorpcja pozostałych kationów) firmyMalvern.

Strukturę krystaliczną hydroksyapatytu i jej zmianę po adsorpcji jonów dwuwartościowych badano za pomocą dyfrakcji promieniowania rentgenowskiego (XRD) za pomocą dyfraktometru Panalytical Empyrean.

\section{WYNIKI I DYSKUSJA WYNIKÓW}

\subsection{KINETYKA ASDORPCJI DWUWARTOŚCIOWYCH KATIONÓW METALI NA HYDROKSYAPATYCIE}

Kinetyka adsorpcji dwuwartościowych kationów metali na hydroksyapatycie $\mathrm{z}$ roztworów o stężeniu początkowym $1 \mathrm{mmol} / \mathrm{dm}^{3}$ przebiega w dwóch etapach: pierwszym szybkim, a drugim - powolnym. Pierwszy etap polega na powierzchniowej adsorpcji/wymianie jonów metali na $\mathrm{H}^{+} / \mathrm{Ca}^{2+}$. Powolny etap jest bardziej skomplikowany i może być związany z dyfuzją jonów w kanale krystalicznym $\mathrm{Ca}$ (II) lub $\mathrm{Ca}(\mathrm{I})$ i/lub innymi procesami, takimi jak rozpuszczanie hydroksyapatytu i wytrącanie nowej fazy stałej[57]. Mały kanał typu I ma średnicę $0,25 \mathrm{~nm}$ i jest otoczony jonami $\mathrm{Ca}^{2+} \mathrm{w}$ pozycji $4 \mathrm{f}$ (4 na komórkę elementarną), Duży kanał typu II ma średnicę $0,45 \mathrm{~nm}$ i jest otoczony przez sześć jonów $\mathrm{Ca}^{2+}$ w położeniu CaII [58], Rys. 3.

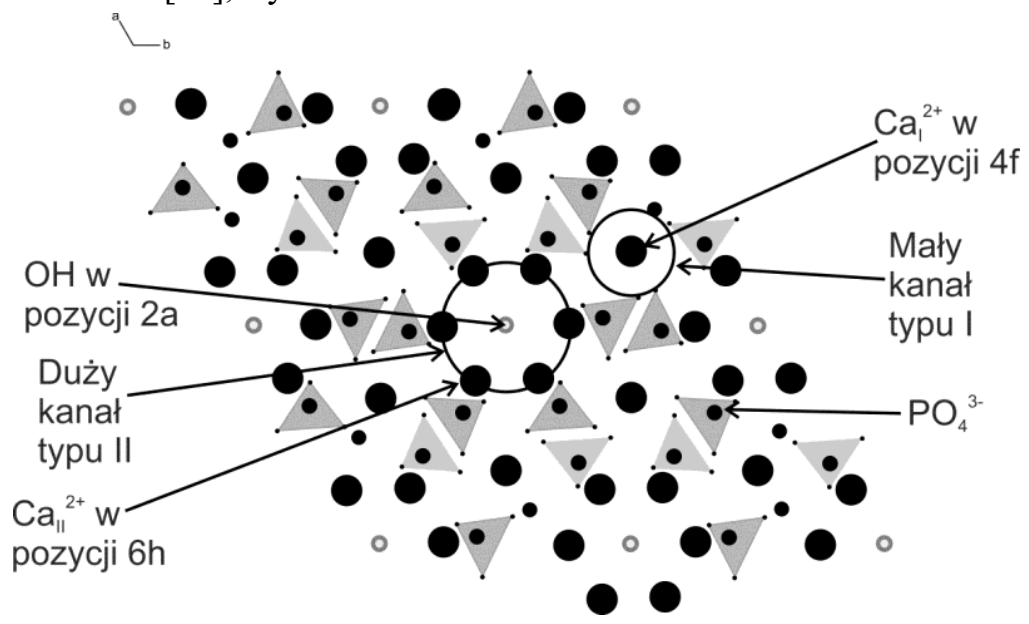

Rysunek 3. Projekcja struktury hydroksyapatytu wzdłuż osi c

Figure 3. Projection of the hydroxyapatite structure along the $\mathrm{c}$ axis 
Najczęściej stosowanymi modelami do opisu kinetyki procesów sorpcji kationów metali $\left(\mathrm{Pb}^{2+}, \mathrm{Cd}^{2+}, \mathrm{Zn}^{2+}, \mathrm{Cu}^{2+}, \mathrm{Co}^{2+}\right)$ na hydroksyapatycie są: modele adsorpcji: rzędu pseudo-pierwszego [28,48,59-63], rzędu pseudo-drugiego [57-62] oraz dyfuzji wewnątrzcząstkowej[60-62]. Analiza dokładności dopasowania obliczonych wartości adsorpcji kationów w funkcji czasu do danych eksperymentalnych wskazuje, że najlepsze dopasowanie uzyskano stosując model pseudo-drugorzędowy. Dla niskiego początkowego stężenia kationu metalu różnica dopasowania jest niewielka, ale różnica ta staje się istotna dla wyższego początkowego stężenia adsorbowanych kationów np. $0.001 \mathrm{~mol} / \mathrm{dm}^{3}$. W większości cytowanych tu prac opisujących szybkość procesu adsorpcji ocenia się, że model rzędu pseudo drugiego lepiej opisuje kinetykę adsorpcji kationów metali na hydroksyapatycie. Janusz i Skwarek badając kinetykę adsorpcji jonów $\mathrm{Sr}^{2+}[46]$, $\mathrm{Ba}^{2+}[47], \mathrm{Cd}^{2+}[42] \mathrm{i} \mathrm{Co}^{2+}[46]$ na hydroksyapatycie uzyskali lepsze dopasowanie adsorpcji w funkcji czasu przy użyciu modelu multi-eksponencjalnego, który jest uogólnieniem równania Lagergrena na szereg równoległych procesów pierwszego rzędu [64]:

$$
\frac{a}{a_{e q}}=1-\frac{\sum_{i+1}^{n} A_{i} \exp (-k, t)}{\sum_{i+1}^{n} A_{i}}=1-\frac{\sum_{i=1}^{n} A_{i} \exp (-k, t)}{1-A_{0}}=1-\sum_{i=1}^{n} \frac{A_{i}}{1-A_{0}} \exp \left(-k_{i} t\right)
$$

Gdzie:

$\mathrm{a}_{\mathrm{e}}$ - adsorpcja równowagowa,

$\mathrm{A}_{0}$ - względna adsorpcja równowagowa,

$\mathrm{n}$ - liczba wyrazów równania (8),

$\mathrm{A}_{\mathrm{i}^{-}}$udział „i”-tego procesu $\mathrm{w}$ adsorpcji charakteryzowanego przez stałą szybkości $\mathrm{k}_{\mathrm{i}}$.

Porównanie dopasowania danych eksperymentalnych kinetyki adsorpcji kationów $\mathrm{Ba}^{2+}$ i $\mathrm{Cd}^{2+}$ na hydroskyapatycie przy użyciu modelu rzędu pseudo drugiego (linie przerywane) i modelu multi-eksponecjalnego(linie ciągłe) przedstawiono na Rys. 4. Jak widać model multi-eksponencjalny pozwala na lepsze opisanie kinetyki adsorpcji kationów na hydroksyapatycie. Dobre dopasowanie modelem multi-eksponencjalnym wskazuje, że proces adsorpcji przebiega dwuetapowo: pierwszy etap szybki adsorpcji, który zachodzi w ciągu kilku minut, po czym następuje drugi etap powolniejszy adsorpcji, w którym adsorpcja osiąga równowagę po 20 minutach. Ten pierwszy etap może być związany $\mathrm{z}$ wymianą jonów $\mathrm{Ca}^{2+}$ na $\mathrm{M}^{2+}$ na powierzchni hydroksyapatytu lub adsorpcją jonów $\mathrm{M}^{2+}$ na grupach wodorofosforanowych. W drugim etapie może dochodzić do dyfuzji jonów $\mathrm{M}^{2+}$ poprzez kanały typu (II) do wnętrza hydroksyapatytu i wymiany jonów $\mathrm{Ca}^{2+}$. Parametry dopasowania kinetyki adsorpcji tych jonów oraz $\mathrm{Co}^{2+}[46], \mathrm{Sr}^{2+}[47]$, $\mathrm{Zn}^{2+}[65]$, i Fe ${ }^{2+}$ zamieszczono w Tabeli 2.

Dokładność dopasowanie obliczeń modelowych w Tabeli 2 charakteryzuje suma kwadratów różnicy adsorpcji obliczonej i eksperymentalnej, parametr 
SSE[66]. Jak widać dokładniejsze dopasowanie kinetyki w/w kationów (mniejsze wartości SSE) uzyskuje się stosując model multi-eksponencjalny. Opisując tym modelem kinetykę adsorpcji kationów $\mathrm{Sr}^{2+}[47], \mathrm{Zn}^{2+}[65], \mathrm{Cd}^{2+}[43], \mathrm{Co}^{2+}[46]$ i $\mathrm{Fe}^{2+}$ dobre dopasowanie uzyskano przy użyciu dwóch członów równania (8), co wskazuje że proces adsorpcji przebiega w dwóch etapach szybkim i powolnym. W przypadku kinetyki adsorpcji kationów $\mathrm{Ba}^{2+}$ na hydroksyapatycie po etapie powolnym, tj. po ok. 200 min. kontaktu roztworu jonów $\mathrm{Ba}^{2+}$ o stężeniu początkowym $1 \mathrm{mmol} / \mathrm{dm}^{3} \mathrm{z}$ hydroksyapatytem, następuje ponowny wzrost adsorpcji[48].

Tabela 2. Parametry równania kinetyki pseudo drugiego rzędu i równania multi-eksponencjalnego adsorpcji wybranych kationów. Dane eksperymentalne kinetyki adsorpcji poszczególnych kationów pochodzą z prac: $\mathrm{Sr}^{2+}[47], \mathrm{Ba}^{2+}[48], \mathrm{Zn}^{2+}[65], \mathrm{Cd}^{2+}[43], \mathrm{Co}^{2+}[46]$

Table 2. Parameters of the pseudo-second order kinetic equation and the multi-exponential equation of adsorption of selected cations. The experimental data of the adsorption kinetics of individual cations come from the works: $\mathrm{Sr}^{2+}[47], \mathrm{Ba}^{2+}[48], \mathrm{Zn}^{2+}[65], \mathrm{Cd}^{2+}[43], \mathrm{Co}^{2+}[46]$

\begin{tabular}{|c|c|c|c|c|c|c|}
\hline \multirow[t]{2}{*}{ Parametry } & \multicolumn{6}{|l|}{ Kation } \\
\hline & $\mathrm{Sr}^{2+}$ & $\mathrm{Ba}^{2+}$ & $\mathrm{Zn}^{2+}$ & $\mathrm{Cd}^{2+}$ & $\mathrm{Co}^{2+}$ & $\mathrm{Fe}^{2+}$ \\
\hline $\mathrm{S}_{\mathrm{w}} \mathrm{m}^{2} / \mathrm{g}$ & 158 & 101 & 104,8 & 52,4 & 158 & 101 \\
\hline $\mathrm{A}_{\max }\left[\mu \mathrm{mol} / \mathrm{m}^{2}\right]$ & 3,16 & 0,99 & 1,91 & 1,91 & 3,16 & 0,99 \\
\hline \multicolumn{7}{|c|}{ Pseudo drugiego rzędu } \\
\hline $\mathrm{a}_{\mathrm{e}}$ & 2,16 & 0,49 & 1,840 & 1,882 & 1,533 & 0,98 \\
\hline $\mathrm{k}_{2}$ & 1,75 & 9,641 & 0,970 & 3,21 & 0,108 & 6,563 \\
\hline SSE & 0,0733 & 0,0024 & 0,0243 & 0,0026 & 0,4050 & 0,0046 \\
\hline \multicolumn{7}{|c|}{ Multi-eksponencjalny } \\
\hline $\mathrm{a}_{\mathrm{eq}}$ & 7,029 & 3,637 & 1,852 & 1,888 & 4,980 & 0,972 \\
\hline $\mathrm{A}_{0}$ & 0,767 & 0,004 & 0,344 & 0,0004 & 0,999 & 0,617 \\
\hline $\mathrm{k}_{1}$ & 2,526 & 1,831 & 0,093 & 7,719 & 0,294 & 2,258 \\
\hline$\overline{A_{1}}$ & 0,066 & 0,128 & 0,152 & 0,908 & 0,00004 & 0,366 \\
\hline $\mathrm{k}_{2}$ & 0,001 & $1,00 \mathrm{e}-7$ & 2,291 & 0,111 & 0,00294 & 0,045 \\
\hline $\mathrm{A}_{2}$ & 0,167 & 0,0855 & 0,503 & 0,091 & 0,000157 & 0,017 \\
\hline $\mathrm{k}_{3}$ & & 0,006 & & & & \\
\hline $\mathrm{A}_{3}$ & & 0,0126 & & & & \\
\hline SSE & 0,0095 & 0,0002 & 0,0052 & 0,0006 & 0,1320 & 0,0020 \\
\hline
\end{tabular}

\section{Gdzie:}

\section{Parametr SSE[66]}

$$
S S E=\sum\left(a_{\text {calc }}-a_{\text {exp }}\right)^{2}
$$

$\mathrm{a}_{\mathrm{exp}}=$ gęstość adsorpcji wyznaczona na podstawie pomiarów,

$\mathrm{a}_{\mathrm{calc}}=$ gęstość adsorpcji obliczona metodą nieliniowego dopasowania parametrów równania pseudo drugiego rzędu lub równania multi-eksponencjalnego.

W tym przypadku do opisu kinetyki adsorpcji zastosowano trzy człony równania multi-eksponecjalnego (8). Ten trzeci etap może być związany z rozpuszczaniem hydroksyapatytu i wytracaniem soli baru. Badania adsorpcji 
jonów $\mathrm{Ba}^{2+} \mathrm{z}$ roztworów o wyższych stężeniach początkowych potwierdziły możliwość takiego mechanizmu adsorpcji[47].

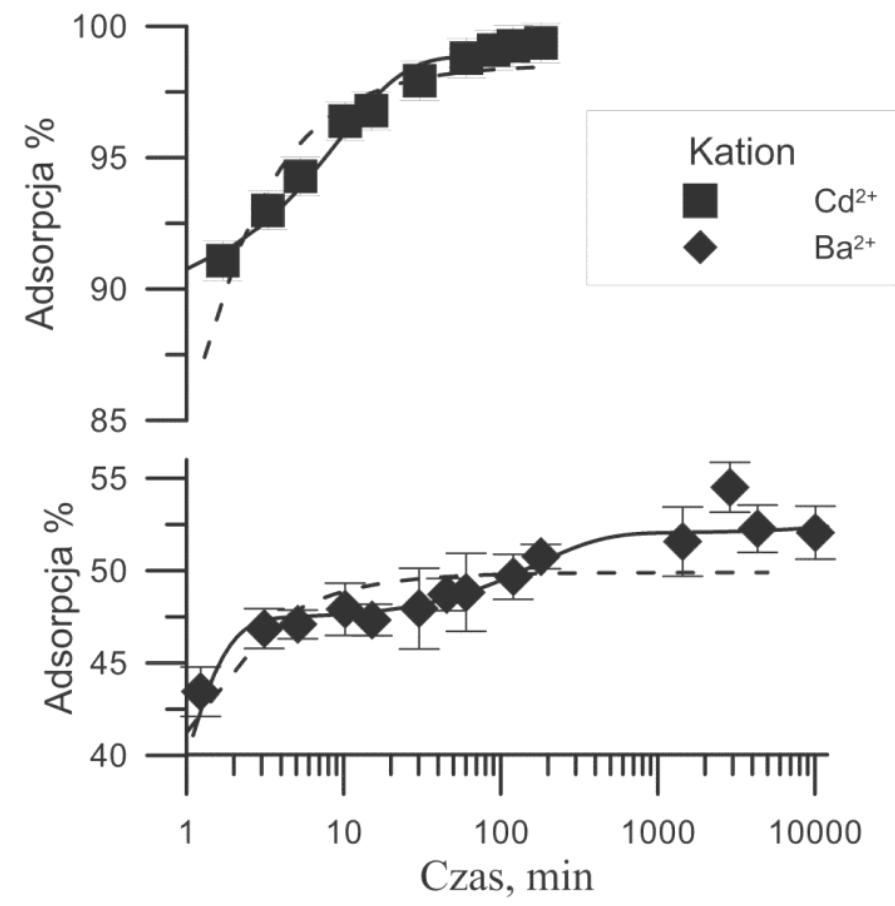

Rysunek 4. Porównanie dopasowania danych eksperymentalnych kinetyki adsorpcji kationów $\mathrm{Ba}^{2+}[47]$ i $\mathrm{Cd}^{2+}[45]$ o stężeniu początkowym $1 \mathrm{mmol} / \mathrm{dm}^{3}$ na hydroskyapatycie przy użyciu modelu rzędu pseudo drugiego (linie przerywane) i modelu multi-eksponecjalnego(linie ciągłe)

Figure 4. Comparison of the fit of the experimental data on the adsorption kinetics of $\mathrm{Ba}^{2+}[47]$ and $\mathrm{Cd}^{2+}[45]$ cations with an initial concentration of $1 \mathrm{mmol} / \mathrm{dm}^{3}$ on hydroxyapatite using a pseudo-second order model (dashed lines) and a multi-exponential model (solid lines)

\subsection{ADSORPCJA KATIONÓW DWUWARTOSCIOWYCH NA HYDROKSYAPATYCIE W FUNKCJI PH}

Rozpuszczalność hydroksyapatytu w roztworach wodnych ogranicza zakres pH, w którym można badać zależność adsorpcji kationów dwuwartościowych w funkcji $\mathrm{pH}$. Zakres ten zawiera się $\mathrm{w}$ przedziale od $\mathrm{pH} 6$ do $\mathrm{pH} \sim 11$. W przedziale tym stężenie jonów $\mathrm{Ca}^{2+}$ pozostających $\mathrm{w}$ równowadze z hydroksyapatytem zmniejsza się przy wzroście pH od 6 do 11 ok. 900 razy, co w związku z reakcją (1) będzie sprzyjać wymianie kationów metalu na wapń w sieci krystalicznej hydroksyaptytu. Ponadto wzrost $\mathrm{pH}$ będzie powodował wzrost adsorpcji kationów metalu w wyniku reakcji ich kompleksowania przez grupy hydroksylowe lub wodorofosforanowe (reakcje 2 i 3 ). 
Rozważając adsorpcję dwuwartościowych kationów metali należy wziąć od uwagę formę w jakiej w danych warunkach występuje kation w roztworze. Kationy $\mathrm{Sr}^{2+} \mathrm{i} \mathrm{Ba}^{2+} \mathrm{w}$ badanym zakresie $\mathrm{pH}$ występują $\mathrm{w}$ formie prostych jonów, natomiast kationy pozostałych badanych metali ulegają reakcjom $\mathrm{z}$ jonami wodorotlenkowymi tworząc kompleksy hydroksowe metali. Jon kobaltu w roztworach o $\mathrm{pH}<8,7$ występuję w postaci jonu $\mathrm{Co}^{2+}$, natomiast w zakresie $\mathrm{pH}>8,7$ do $\mathrm{p}<9,7$ dominuje rozpuszczalna forma $\mathrm{Co}(\mathrm{OH})_{2}$, zaś w roztworach o $\mathrm{pH}>9,7$ forma anionowa $\mathrm{Co}(\mathrm{OH})_{3}{ }^{-}$. Podobnie zmienia się udział form cynku w roztworach o $\mathrm{pH}<8,5$ cynk występuje głownie w postaci $\mathrm{Zn}^{2+}$, powyżej do $\mathrm{pH}<12 \mathrm{w}$ postaci rozpuszczalnej formy $\mathrm{Zn}(\mathrm{OH})_{2}$. Natomiast jony $\mathrm{Cd}^{2+} \mathrm{i} \mathrm{Fe}^{2+}$ w postaci prostych jonów występują odpowiednio w roztworach o $\mathrm{pH}<9,7, \mathrm{pH}<9,3$, powyżej tych wartości pH dominują formy kationów koordynowane przez jedna grupę hydroksylową.

Kationy metalu dwuwartościowego koordynowane przez jeden jon wodorotlenkowy mogą ulegać reakcjom kompleksowania powierzchniowego przez grupy wodorotlenowe lub wodorofosforanowe hydroskyapatytu wg reakcji 10:

$$
\mathrm{HAp}-\mathrm{OH}+\mathrm{MOH}^{+} \leftrightarrow \mathrm{HAp}-\mathrm{O}-\mathrm{MOH}+\mathrm{H}^{+}
$$

Natomiast kationy metalu dwuwartościowego koordynowane przez dwa jony wodorotlenkowe mogą ulegać adsorpcji fizycznej na powierzchni hydroksyapatytu lub reakcji 11:

$$
\mathrm{HAp}-\mathrm{OH}+\mathrm{M}(\mathrm{OH})_{2} \leftrightarrow \mathrm{HAp}-\mathrm{O}-\mathrm{MOH}+\mathrm{H}_{2} \mathrm{O}
$$

$\mathrm{Na}$ Rys. 5 i 6 przedstawiono zależność adsorpcji kationów metali na hydroksyapatycie w funkcji pH odpowiednio dla stężeń początkowych kationu w roztworze $1 \mu \mathrm{mol} / \mathrm{dm}^{3}$ i $1 \mathrm{mmol} / \mathrm{dm}^{3}$. Ponieważ porównywano adsorpcję na różnych próbkach hydroksyaptytu, przedstawiono zależność adsorpcji wyrażoną $\mathrm{w}$ procentach, tj. obliczono procent kationów ulegających adsorpcji w stosunku do ich stężenia początkowego. Jak widać adsorpcja $\mathrm{z}$ roztworów o stężeniu początkowym kationów $1 \mu \mathrm{mol} / \mathrm{dm}^{3} \mathrm{w}$ przypadku jonów $\mathrm{Cd}^{2+}, \mathrm{Zn}^{2+} \mathrm{i} \mathrm{Co}^{2+}$ osiąga $\sim 100 \%$, co świadczy o wysokim powinowactwie adsorpcyjnym tych jonów do hydroskyapatytu. W przypadku jonów $\mathrm{Ba}^{2+}$ obserwuje się wzrost adsorpcji w zakresie pH od 7 do 9, powyżej którego adsorpcja osiąga $\sim 100 \%$, Rys 5. Natomiast adsorpcja jonów $\mathrm{Sr}^{2+}$ rośnie ze wzrostem $\mathrm{pH}$ w całym badanym zakresie pH, co może świadczyć o mniejszym powinowactwie tych jonów do powierzchni hydroksyapatytu i dużym udziale reakcji kompleksowania jonów $\mathrm{Sr}^{2+}$ przez grupy hydroksylowe lub wodorofosforanowe.

W przypadku stężenia początkowego kationów metalu dwuwartościowego równego $1 \mathrm{mmol} / \mathrm{dm}^{3}$, jony $\mathrm{Cd}^{2+} \mathrm{i} \mathrm{Fe}^{2+} \mathrm{w}$ całym badanym zakresie $\mathrm{pH}$ ulegają $\sim 100 \%$ adsorpcji, co świadczy o wysokim powinowactwie adsorpcyjnym tych jonów do hydrokysapatytu. W przypadku pozostałych jonów, tj. $\mathrm{Sr}^{2+}, \mathrm{Ba}^{2+}, \mathrm{Co}^{2+}$ 
i $\mathrm{Zn}^{2+}$ adsorpcja jonów rośnie wraz ze wzrostem $\mathrm{pH}$. Efekt ten może być związany zarówno z wymianą kationów metalu z jonami wapnia sieci krystalicznej, jak i reakcjami kompleksowania. Należy zaznaczyć, że w przypadku adsorpcji $\mathrm{z}$ roztworów o stężeniu początkowym $1 \mathrm{mmol} / \mathrm{dm}^{3}$ maksymalna gęstość adsorpcji jonów, jest mniejsza niż stężenie jonów lub grup powierzchniowych na hydroksyapatycie. Obliczone na podstawie danych krystalograficznych i pomiarów radiochemicznych stężenie jonów $\mathrm{Ca}^{2+}$ na powierzchni HAp wynosi $7,5 \mu \mathrm{mol} / \mathrm{m}^{2}$, stężenie jonów fosforanowych $5,0 \mu \mathrm{mol} / \mathrm{m}^{2}$, a grup wodorotlenowych $4,15 \mu \mathrm{mol} / \mathrm{m}^{2}$ [34]. Ze względu na rozmiar kationów $\mathrm{Ba}^{2+} \mathrm{w}$ porównaniu do jonów $\mathrm{Ca}^{2+}$ można oczekiwać, że proces wymiany $\mathrm{z}$ jonami wapnia może być ograniczony do warstwy powierzchniowej jonów, natomiast dyfuzja w głąb kryształu w kanałach będzie ograniczona do kanałów typu II. Jony o małych rozmiarach jak $\mathrm{Co}^{2+} \mathrm{i} \mathrm{Fe}^{2+}$ mogą dyfundować w obu typach kanałów. Zaskoczeniem jest przebieg adsorpcji jonów $\mathrm{Co}^{2+}$, których zależność adsorpcji $\mathrm{w}$ funkcji $\mathrm{pH}$ przypomina zależność adsorpcji kationów na granicy faz tlenek metalu roztwór elektrolitu, z tym, że dla tych układów adsorpcja zmienia się w zakresie od 0 do $100 \%$. $\mathrm{W}$ przypadku jonów $\mathrm{Co}^{2+}$ zmiana ta zachodzi w zakresie od 30 do $100 \%$, co może wskazywać na znaczny udział $\mathrm{w}$ adsorpcji jonów $\mathrm{Co}^{2+}$ wymiany jonowej $\mathrm{z}$ jonami wapnia.

W celu określenia udziału reakcji kompleksowania kationów metali w ich adsorpcji określono gęstość desorpcji jonów $\mathrm{H}^{+} \mathrm{w}$ reakcjach (2)-(5). Gęstość desorpcji jonów $\mathrm{H}^{+}$obliczono na podstawie miareczkowania potencjometrycznego porównując krzywą miareczkowania elektrolitu i krzywą miareczkowania suspensji. Przykładowe wyniki desorpcji jonów $\mathrm{H}^{+} \mathrm{w}$ funkcji $\mathrm{pH}$ w nieobecności i obecności jonów $\mathrm{Cd}^{2+}$ o stężeniu początkowym $1 \mathrm{mmol} / \mathrm{dm}^{3}$ w układzie hydroksyapatyt/roztwór $1 \mathrm{mmol} / \mathrm{dm}^{3} \mathrm{NaCl}$ przedstawiono na Rys 7 .

Zakładając, że rozpuszczalność hydroksyapatytu w obu układach jest podobna, gęstość zdesorbowanych jonów $\mathrm{H}^{+}$pod wpływem adsorpcji kationów metali uzyskano odejmując zależność desorpcji jonów $\mathrm{H}^{+}$w układzie, w którym adsorbowały się kationy metalu od zależności uzyskanej dla suspensji bez kationów metalu dwuwartościowego. Następnie uzyskaną różnicę podzielono przez gęstość adsorpcji kationów dwuwartościowych na hydroksyapatycie w celu określenia liczby jonów wodorowych uwalnianych przez jeden adsorbujący się kation metalu, Rys. 8. W obliczeniach dla jonów $\mathrm{Zn}^{2+}, \mathrm{Cd}^{2+}, \mathrm{Fe}^{2+}$ i $\mathrm{Co}^{2+}$ uwzględniano reakcje powstawania hydroksokomplesów metali. Jak widać z zależności przedstawionych na Rys. 8, adsorpcja jonów $\mathrm{Sr}^{2+}$ na hydroskyapatycie jest związana $\mathrm{z}$ procesem wymiany jonowej, reakcja 1 . Podobnie mały udział reakcji kompleksowania w adsorpcji jest w przypadku jonów $\mathrm{Co}^{2+}$ do $\mathrm{pH}=8.5$, zaś powyżej tej wartości $\mathrm{pH}$ udział ten rośnie. Podobnie w przypadku jonów $\mathrm{Ba}^{2+}$, gdzie udział reakcji komple- 
ksowania staje się znaczący powyżej $\mathrm{pH}=7$. W przypadku jonów $\mathrm{Cd}^{2+}$ i $\mathrm{Zn}^{2+}$ udział reakcji kompleksowania $\mathrm{w}$ adsorpcji rośnie ze wzrostem $\mathrm{pH}$ od $6 \mathrm{w}$ przypadku jonów $\mathrm{Zn}^{2+}$ i $\mathrm{pH}=8 \mathrm{w}$ przypadku jonów $\mathrm{Cd}^{2+}$, ale dopiero przy $\mathrm{pH}=9$, jeden adsorbujący się kation uwalnia jeden jon $\mathrm{H}^{+}$.

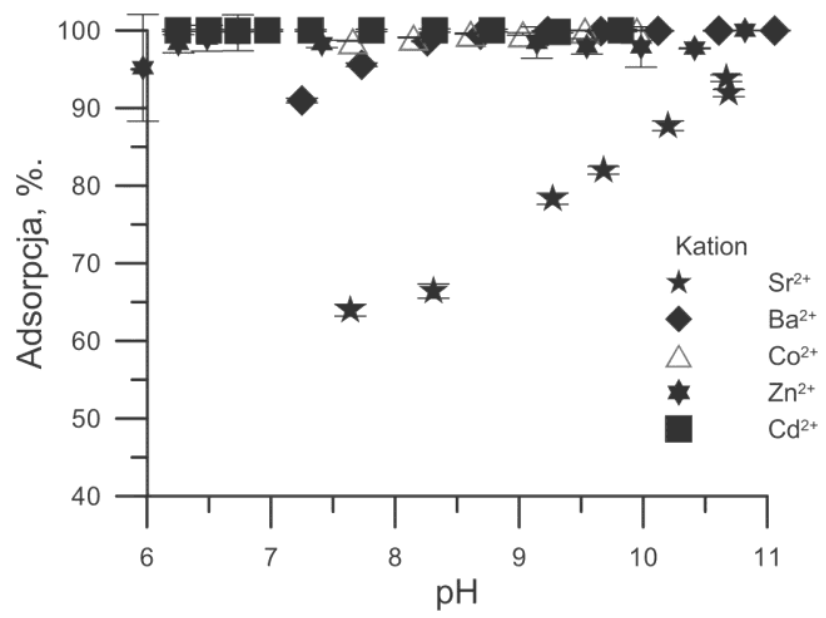

Rysunek 5. Zależność adsorpcji wybranych kationów z roztworu o stężeniu początkowym $1 \mu \mathrm{mol} / \mathrm{dm}^{3}$ na hydroksyapatycie w funkcji $\mathrm{pH}$

Figure 5. The dependence of the adsorption of selected cations from a solution with an initial concentration of $1 \mu \mathrm{mol} / \mathrm{dm}^{3}$ on hydroxyapatite as a function of $\mathrm{pH}$

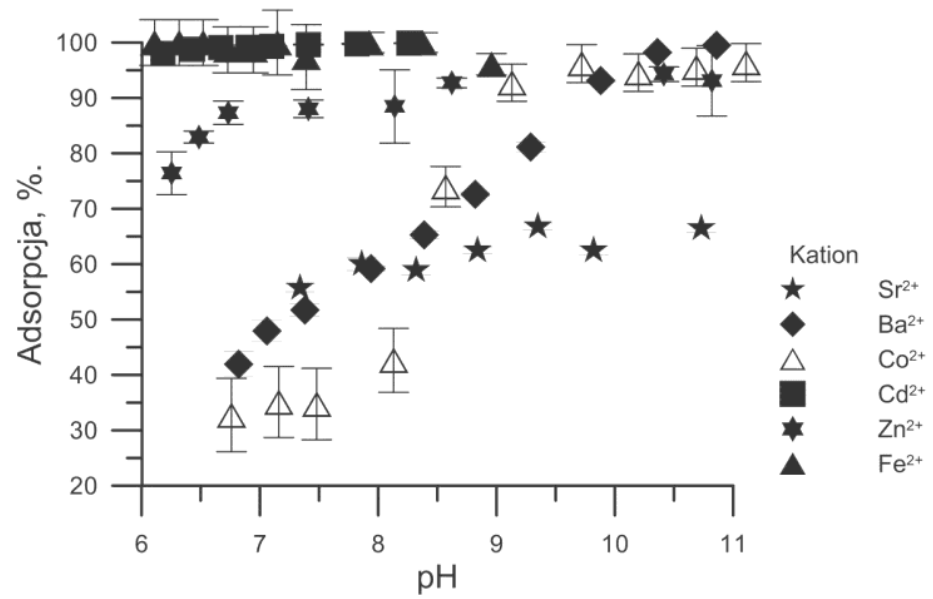

Rysunek 6. Zależność adsorpcji wybranych kationów z roztworu o stężeniu początkowym $1 \mathrm{mmol} / \mathrm{dm}^{3}$ na hydroksyapatycie w funkcji $\mathrm{pH}$

Figure 6. The dependence of the adsorption of selected cations from a solution with an initial concentration of $1 \mathrm{mmol} / \mathrm{dm}^{3}$ on hydroxyapatite as a function of $\mathrm{pH}$ 


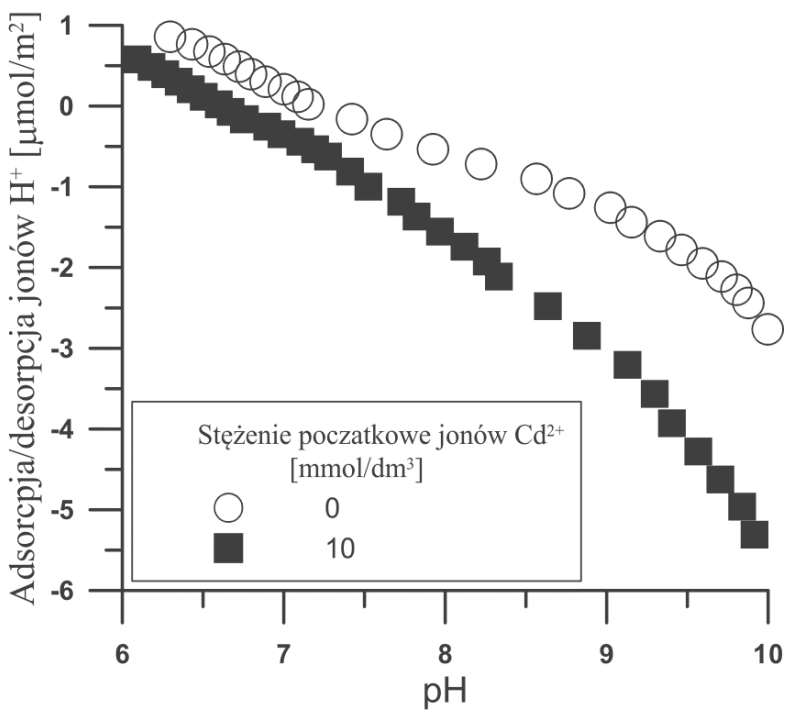

Rysunek 7. Porównanie desorpcji jonów $\mathrm{H}^{+} \mathrm{w}$ funkcji $\mathrm{pH}$ przy braku lub $\mathrm{w}$ obecności jonów $\mathrm{Cd}^{2+}$ o stężeniu początkowym $1 \mathrm{mmol} / \mathrm{dm}^{3}$ w układzie hydroksyapatyt $/ 1 \mathrm{mmol} / \mathrm{dm}^{3}$ roztwór $\mathrm{NaCl}$

Figure 7. Comparison of $\mathrm{H}^{+}$ion desorption as a function of $\mathrm{pH}$ in the absence and presence of $\mathrm{Cd}^{2+}$ ions with an initial concentration of $1 \mathrm{mmol} / \mathrm{dm}^{3}$ in the hydroxyapatite $/ 1 \mathrm{mmol} / \mathrm{dm}^{3}$ solution $\mathrm{NaCl}$ system

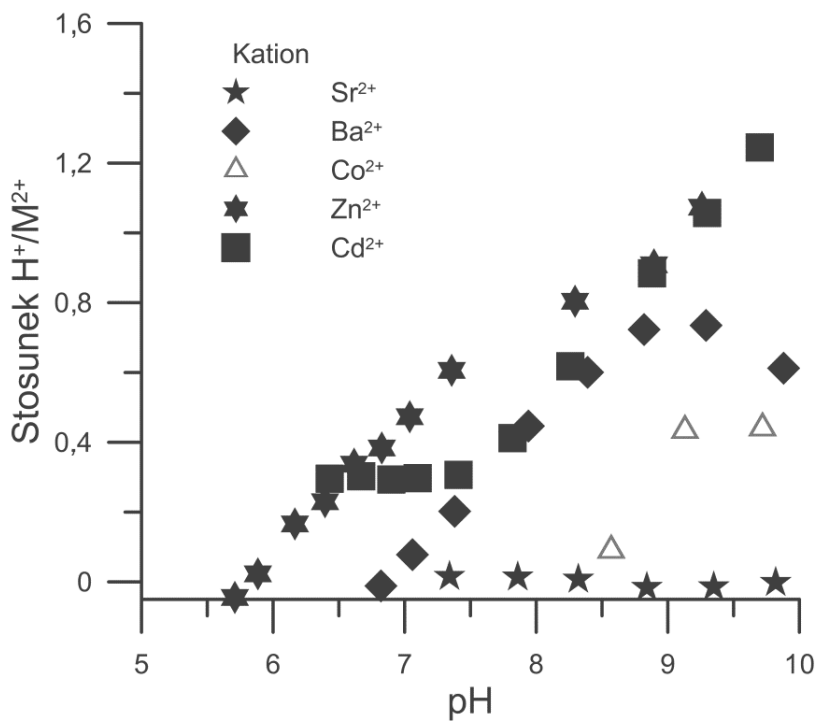

Rysunek 8. Stosunek liczby zdesorbowanych jonów $\mathrm{H}^{+}$na skutek adsorpcji jonów metalu do liczby zaadsorbowanych jonów metalu na hydroskyapatycie w funkcji $\mathrm{pH}$

Figure 8. The ratio of number desorbed $\mathrm{H}^{+}$ions due to adsorption of metal ions to number adsorbed metal ions on hydroxyapatite as a function $\mathrm{pH}$ 


\subsection{WPLYW ADSORPCJI KATIONÓW DWUWARTOŚCIOWYCH NA HYDROKSYAPATYCIE NA POTENCJAŁ DZETA}

Badania wpływu adsorpcji jonów dwuwartościowych na hydroksyapatycie na zależność potencjału dzeta $\mathrm{w}$ funkcji $\mathrm{pH}$ pozwalają nie tylko na interpretację mechanizmu adsorpcji jonów na tej granicy faz, ale również na dyskusję stabilności dyspersji hydroksyapatytu w roztworach elektrolitów[43,46-48,65]. Wartość potencjału dzeta $\mathrm{w}$ zakresie $\mathrm{pH}$, w którym badano adsorpcję jonów dwuwartościowych w roztworze elektrolitu podstawowego $\left(1 \mathrm{mmol} / \mathrm{dm}^{3} \mathrm{NaCl}\right)$, jest ujemna i zmniejsza się ze wzrostem pH. Jest to spowodowane większym powinowactwem jonów fosforanowych do powierzchni hydroskyapatytu niż jonów wapniowych. Adsorpcja jednego kationu dwuwartościowego na jednej grupie hydroksylowej lub wodorofosforanowej spowoduje spadek gęstości ładunku powierzchniowego o jedną jednostkę elektrostatyczną, jednocześnie wprowadza do warstwy zwartej ładunek dodatni o wartości dwóch jednostek elektrostatycznych. W wyniku tego procesu, przy dostatecznie dużej adsorpcji, może dojść od zmiany znaku ładunku w warstwie dyfuzyjnej (tzw. charge reversal), oznaczany jako CR2. Efekt ten obserwowano podczas adsorpcji kationów $\mathrm{Cd}^{2+}[43], \mathrm{Co}^{2+}[46]$. Odwrócenie ładunku powierzchniowego może nastąpić, także w wyniku adsorpcji dwuwartościowego kationu na ujemnie naładowanej grupie powierzchniowej np. w przypadku adsorpcji $\mathrm{Sr}^{2+}$ na hydroksyapatycie [47]. Adsorpcja kationów dwuwartościowych na dwóch ujemnie naładowanych grupach powierzchniowych hydroskyapatytu powoduje kompensację ladunku powierzchniowego w warstwie zwartej i zmniejszenie wartości bezwzględnej ładunku warstwy dyfuzyjnej (zmniejszenie wartości bezwzględnej potencjału dzeta). Efekt ten obserwowano w przypadku adsorpcji jonów $\mathrm{Ba}^{2+}$ na hydroskyapatycie[48].

Zmniejszenie wartości bezwzględnej potencjału dzeta prowadzi do osłabienia opychającego cząstek hydroksyapatytu i sprzyja ich agregacji. Podobnie w pewnym zakresie $\mathrm{pH}$, poniżej i powyżej CR2, małe wartości potencjału dzeta mogą powodować osłabienie oddziaływań elektrostatycznych i sprzyjać agregacji cząstek hydroksyaptytu[48].

\subsection{WPLYW ADSORPCJI KATIONÓW DWUWARTOŚCIOWYCH NA HYDROKSYAPATYCIE NA ROZKŁAD ZIARNOWY CZĄSTEK HYDROKSYAPATYTU}

Analiza wielkości cząstek hydrosyapatytu w roztworach elektrolitu powala śledzić procesy dyspersji lub agregacji cząstek fazy zdyspergowanej. W połączeniu $\mathrm{z}$ analizą XRD może być pomocna $\mathrm{w}$ potwierdzeniu przebiegu procesu rozpuszczania hydroksyapatytu i wytrącania nowej fazy dwuwartościowych kationów na hydroksyapatycie. 
Rozkład ziarnowy próbek hydroksyapatytu kontaktującego się z roztworem kationów dwuwartościowych metali, których adsorpcja osiąga $\sim 100 \% \mathrm{np} . \mathrm{Cd}^{2+}$, wskazuje na nieznaczne przesunięcie krzywej rozkładu w kierunku wyższych wartości średnic cząstek, Rys. 9.

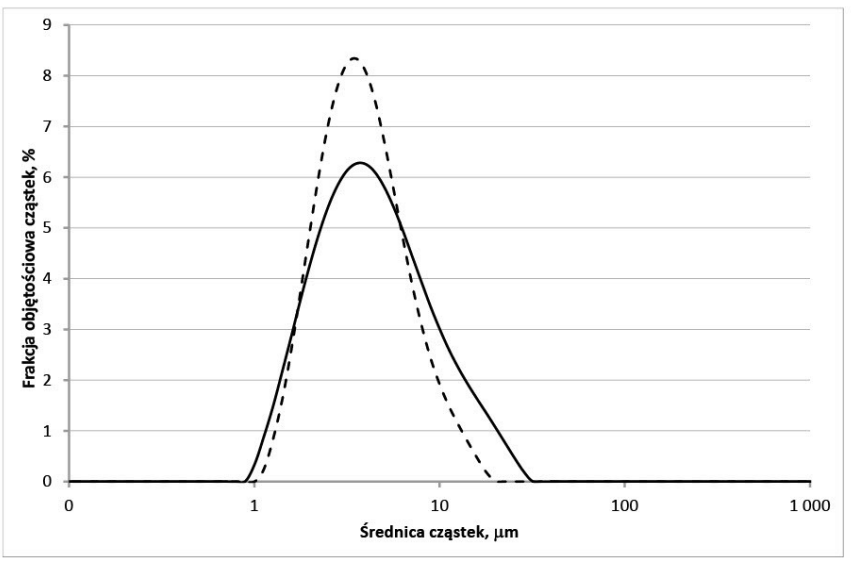

Rysunek 9. Rozkład objętościowy cząstek HAp w roztworze $1 \mathrm{mmol} / \mathrm{dm}^{3} \mathrm{NaCl}$ (linia przerywana) i w roztworze $1 \mathrm{mmol} / \mathrm{dm}^{3} \mathrm{NaCl}+1 \mathrm{mmol} / \mathrm{dm}^{3} \mathrm{Cd}^{2+}$ (linia ciagła)

Figure 9. Volume distribution of HAp particles in $0.001 \mathrm{NaCl}$ solution (dashed line) and $1 \mathrm{mmol} / \mathrm{dm}^{3}$ $\mathrm{NaCl}+1 \mathrm{mmol} / \mathrm{dm}^{3} \mathrm{Cd}^{2+}$ solution (solid line)

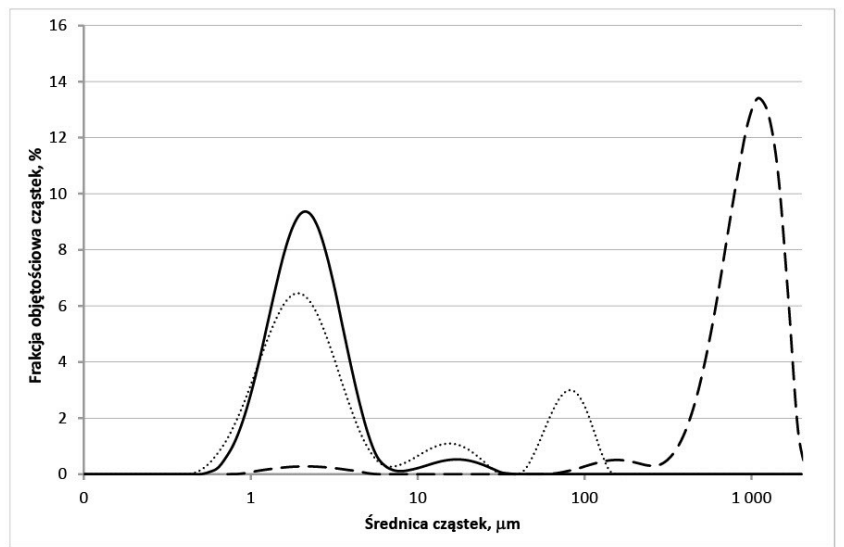

Rysunek 10. Rozkład objętościowy cząstek $\mathrm{HAp}$ w roztworzel $\mathrm{mmol} / \mathrm{dm}^{3} \mathrm{NaCl}$ (linia ciągła), w roztworze $1 \mathrm{mmol} / \mathrm{dm}^{3} \mathrm{NaCl}+1 \mathrm{mmol} / \mathrm{dm}^{3} \mathrm{Ba}^{2+}$ (linia kropkowana) i w roztworze $1 \mathrm{mmol} / \mathrm{dm}^{3} \mathrm{NaCl}$ $+5 \mathrm{mmol} / \mathrm{dm}^{3} \mathrm{Ba}^{2+}$ (linia przerywana)

Figure 10. Volume distribution of HAp particles in $1 \mathrm{mmol} / \mathrm{dm}^{3} \mathrm{NaCl}$ solution (solid line), in $1 \mathrm{mmol} / \mathrm{dm}^{3}$ $\mathrm{NaCl}+1 \mathrm{mmol} / \mathrm{dm}^{3} \mathrm{Ba}^{2+}$ solution (dotted line) and in $1 \mathrm{mmol} / \mathrm{dm}^{3} \mathrm{NaCl}+5 \mathrm{mmol} / \mathrm{dm}^{3} \mathrm{Ba}^{2+}$ solution (dashed line) 
W przypadku układu HAp/roztwór $1 \mathrm{mmol} / \mathrm{dm}^{3}$ jonów $\mathrm{Ba}^{2+}$ obserwuje się rozkład trimodalny spowodowany powstaniem agregatów o dużych rozmiarach na skutek ekranowania ujemnego ładunku elektrycznego hydroksyapatytu w warstwie dyfuzyjnej przez obecne $\mathrm{w}$ roztworze jony $\mathrm{Ba}^{2+}$, Rys. 10. Jak widać, kondycjonowanie dyspersji hydroksyapatytu $\mathrm{w}$ roztworze $1 \mathrm{mmol} / \mathrm{dm}^{3} \mathrm{NaCl}$ powoduje agregację cząstek HAp (pojawia się frakcja od 8-36 $\mu \mathrm{m}$ ), ale w obecności jonów $\mathrm{Ba}^{2+}$ o stężeniu początkowym $1 \mathrm{mmol} / \mathrm{dm}^{3}$ koagulacja prowadzi do

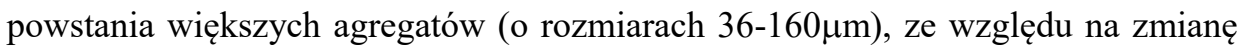
wartości potencjału zeta przy $\mathrm{pH}=7,0 \mathrm{z}-21 \mathrm{mV}$ (w nieobecności jonów $\mathrm{Ba}^{2+}$ ) do -1 $\mathrm{mV}$ w obecności jonów $\mathrm{Ba}^{2+}$ o stężeniu początkowym $1 \mathrm{mmol} / \mathrm{dm}^{3}$ (na skutek osłabienia oddziaływań elektrostatycznych między cząstkami HAp). Natomiast obecność w suspensji hydroksyapatytu jonów $\mathrm{Ba}^{2+}$ o stężeniu początkowym $5 \mathrm{mmol} / \mathrm{dm}^{3}$ powoduje zanik frakcji drobnych cząstek hydroksapatytu i powstanie frakcji agregatów o rozmiarach 200-2000 $\mu \mathrm{m}$.

\subsection{WPLYW ADSORPCJI KATIONÓW DWUWARTOŚCIOWYCH NA HYDROKSYAPATYCIE NA STRUKTURĘ KRYSTALICZNĄ HYDROKSYAPATYTU I JEGO KRYSTALICZNOŚĆ}

Wpływ adsorpcji jonu dwuwartościowego na hydroksyapatycie na jego strukturę krystaliczną został udokumentowany badaniami XRD. Badania wykazały, że przy niskim stężeniu jonów metali w układzie HAp/roztwór elektrolitu wpływ parametrów komórki elementarnej kryształu zmienia się nieznacznie i zależy od wielkości zaadsorbowanego jonu[49,63,67]. Natomiast w przypadku wyższych stężeń adsorbującego się na hydroksyapatycie kationu w dyfraktogramie XRD hydroksyapatytu pojawiają się refleksy nowej fazy[27,68,69].

W celu określenia zmian parametrów komórki elementarnej wywołanej adsorpcją kationów dwuwartościowych, w badaniach adsorpcji kationów: $\mathrm{Cd}^{2+}[43]$, $\mathrm{Co}^{2+}[46], \mathrm{Fe}^{2+}, \mathrm{Ba}^{2+}[48]$ i $\mathrm{Zn}^{2+}[65]$, zastosowano metodę Rietvelda do analizy dyfraktogramów XRD próbek hydroksyapatytu i próbek HAp z zaadsorbowanymi jonami dwuwartościowymi z roztworów o stężeniu początkowym $1 \mathrm{mmol} / \mathrm{dm}^{3}$. Wyniki obliczeń zamieszczono w Tabeli 3.

Jak widać, udoskonalenie Rietvelda daje nieco wyższe wartości parametrów a i c komórki elementarnej sieci w porównaniu z wartościami z kart PDF 00-0090432 i 00-064-0738, chociaż parametry dopasowania ( $\operatorname{Sig}$ i $\mathrm{R}_{\mathrm{wp}}$ ) są całkiem dobre. Różnica ta może wynikać z obecności jonów węglanowych, które zastępują grupy hydroksylowe[71]. 
Tabela 3. Parametry a i c komórki elementarnej próbek hydroksyapatytu i parametry dopasowania, Sig i $\mathrm{R}_{\mathrm{wp}}$, metodą Rietvelda przy użyciu programu Maud[70]

Table 3. Unit cell a and c parameters of hydroxyapatite samples and fit parameters, Sig and $R_{w p}$, by Rietveld using Maud [70]

\begin{tabular}{|c|c|c|c|c|c|c|}
\hline Kod próbki & Kation & $\mathrm{a}[\mathrm{nm}]$ & $\mathrm{c}[\mathrm{nm}]$ & $\mathrm{V}\left[\mathrm{nm}^{3}\right]$ & Sig & $\begin{array}{l}\text { Rwp } \\
{[\%]}\end{array}$ \\
\hline HAp_K & & $0,94262(2)$ & $0,68856(1)$ & 0,523 & 3,93 & 6,50 \\
\hline HAp & $\mathrm{Ba}^{2+}$ & $0,94225(2)$ & $0,68825(1)$ & 0,529 & 2,82 & 3,85 \\
\hline HAp & & $0,94200(2)$ & $0,68757(1)$ & 0,528 & 2,45 & 6,13 \\
\hline HAp & $\mathrm{Fe}^{2+}$ & $0,94179(3)$ & $0,68660(2)$ & 0,527 & 2.40 & 3,78 \\
\hline HAp S1 & & $0,94195(3)$ & $0,68849(2)$ & 0,529 & 1,86 & 2,29 \\
\hline HAp_S1 & $\mathrm{Zn}^{2+}$ & $0,94113(3)$ & $0,68782(2)$ & 0,527 & 2,09 & 2,56 \\
\hline HAp S3 & & $0,94412(1)$ & $0,68754(1)$ & 0,553 & 2,22 & 3,39 \\
\hline HAp S3 & $\mathrm{Cd}^{2+}$ & $0,94333(2)$ & $0,68680(1)$ & 0,529 & 3,00 & 4,47 \\
\hline HAp S2 & & $0,94195(1)$ & $0,68686(1)$ & 0,527 & 2,09 & 7,12 \\
\hline HAP_S2/ & $\mathrm{Sr}^{2+}$ & $0,943645(1)$ & $6.8856(1)$ & 0,531 & 1,37 & 4,08 \\
\hline HAP_S2 & $\mathrm{Co}^{2+}$ & $0,94162(1)$ & $0,68658(2)$ & 0,527 & 2,00 & 6,64 \\
\hline Nr karty PDF & & $\mathrm{a}[\mathrm{nm}]$ & $\mathrm{c}[\mathrm{nm}]$ & $\mathrm{V}\left[\mathrm{nm}^{3}\right]$ & & \\
\hline $00-009-0432$ & & 0,94180 & 0,68840 & 0,528 & & \\
\hline $00-064-0738$ & & 0,94210 & 0,68800 & 0,528 & & \\
\hline $0,8 \%$ A C-HAp[71] & & $0,94468(4)$ & $0,68001(3)$ & 0,532 & & \\
\hline $1 \%$ B C-HAp [71] & & $0,94234(2)$ & $0,68801(3)$ & 0,529 & & \\
\hline
\end{tabular}

Adsorpcja dwuwartościowych jonów metali prowadzi do niewielkiego obniżenia parametrów komórki elementarnej. Dla $\mathrm{Cd}^{2+}, \mathrm{Zn}^{2+}, \mathrm{Co}^{2+} \mathrm{i} \mathrm{Fe}^{2+}$ parametry sieci krystalicznej HAp maleją ze względu na mniejsze promienie jonowe $\mathrm{Cd}^{2+}, \mathrm{Zn}^{2+}$, $\mathrm{Co}^{2+}, \mathrm{i} \mathrm{Fe} 2+\mathrm{w}$ stosunku do jonów $\mathrm{Ca}^{2+}$. Wykazano, że podstawienie jonów $\mathrm{Sr}^{2+}$ i $\mathrm{Ba}^{2+} \mathrm{w}$ miejsce jonów $\mathrm{Ca}^{2+}$ w kryształach hydroksyapatytu prowadzi do wzrostu parametrów sieci krystalicznej, ale wykazano również, że wpływ na te wartości mają zastosowane metody syntezy[71].

Badania adsorpcji $\mathrm{Zn}^{2+}$ na hydroskyapatycie wykazały, że adsorpcja $\mathrm{Zn}^{2+}$ prowadzi do zmniejszenia rozmiaru kryształów i krystaliczności próbek hydroksyapatytu[28]. W celu określenia wpływu domieszkowania kationami hydroskyapatytu na krystaliczność próbek obliczono wielkość krystalitów przy użyciu równania Scherrera i FWHM dla odbić (002) i (300)[72] oraz współczynników krystaliczności metodą Landi i współpr.[73] oraz metodą Person i współpr.[74]. Wyniki obliczeń zamieszczono w Tabeli 4. Adsorpcja dwuwartościowych jonów metali tylko nieznacznie zmienia rozmiar kryształów i stopień krystaliczności CI[73] lub CI_XRD[74]. Niewielkie zmiany wielkości kryształów po adsorpcji dwuwartościowych jonów $\mathrm{z}$ roztworu o stężeniu mniejszym/równym $1 \mathrm{mmol} / \mathrm{dm}^{3}$ dowodzą mechanizmu adsorpcji tych jonów 
poprzez wymianę jonową i adsorpcję na grupie hydroksylowej powierzchni HAp. Nie mniej jednak w przypadku adsorpcji kationów z roztworów o większym stężeniu początkowym kationu, dyfraktogramy próbek wskazują na obecność, obok hydroksyapatytu, innej fazy stałej, co dowodzi o przebiegu procesów rozpuszczania i wytrącania nowej fazy w układzie hydroksyapatyt roztwór elektrolitu. Na Rys. 11 przedstawiono porównanie dyfraktogramów próbek hydroksyapatytu kondycjonowanego w roztworach stężeniu początkowym 1 i $10 \mathrm{mmol} / \mathrm{dm}^{3}$ jonów $\mathrm{Ba}^{2+}$. Jak widać dyfraktogram dla stężenia $1 \mathrm{mmol} / \mathrm{dm}^{3}$ jonów $\mathrm{Ba}^{2+}$ odpowiada strukturze heksagonalnej hydroskyapatytu, natomiast dla próbki kondycjonowanej w roztworze $10 \mathrm{mmol} / \mathrm{dm}^{3} \mathrm{Ba}^{2+}$ obserwuje się dodatkowe piki, których położenie nie odpowiada strukturze fosforanów baru opisanej na kartach PDF.

Tabela 4. Obliczone wartości wielkości kryształu przy użyciu równania Scherrera i FWHM (002) i (300) oraz współczynniki krystaliczności próbek hydroksyapatytu

Table 4. Calculated values of crystal size using the Scherrer and FWHM equation (002) and (300) and the crystallinity coefficients of the hydroxyapatite samples

\begin{tabular}{|c|c|c|c|c|c|}
\hline Sample code & $\mathrm{D}_{(002)}[\mathrm{nm}]$ & $\mathrm{D}_{(300)}[\mathrm{nm}]$ & $\mathrm{D}_{(002)} / \mathrm{D}_{(300)}$ & CI [\%][73] & CI_XRD[74] \\
\hline HAP K & $28,9 \pm 0,1$ & $17,0 \pm 0,1$ & 1,70 & 20,14 & 9,11 \\
\hline $\mathrm{HAp} \mathrm{K} / \mathrm{Ba}^{2+}$ & $29,6 \pm 0,1$ & $15,5 \pm 0,3$ & 1,91 & 20,00 & 9,17 \\
\hline HAP_K & $25,4 \pm 0,2$ & $13,5 \pm 0,1$ & 1,88 & 15,51 & 8,32 \\
\hline $\mathrm{HAp} \_\mathrm{K} / \mathrm{Fe}^{2+}$ & $26,5 \pm 0,2$ & $17,3 \pm 0,2$ & 1,53 & 9,02 & 6,52 \\
\hline HAP S1 & $29,3 \pm 0,2$ & $15,4 \pm 0,2$ & 1,89 & 33,99 & 9,99 \\
\hline HAP $\mathrm{S} 1 / \mathrm{Zn}^{2+}$ & $29,6 \pm 0,3$ & $15,7 \pm 0,2$ & 1,77 & 31.74 & 9,91 \\
\hline HAP S3 & $48,8+1.1$ & $22.5+10$ & 2.17 & 56,13 & 7.87 \\
\hline HAP $\mathrm{S} 3 / \mathrm{Cd}^{2+}$ & $48,4 \pm 1,0$ & $27,5 \pm 0,3$ & 1,76 & 55,53 & 7,94 \\
\hline HAP S2 & $692+18$ & $576+11$ & 120 & 70,38 & 8.78 \\
\hline $\mathrm{HAP} \mathrm{S} 2 / \mathrm{Co}^{2+}$ & $52,4 \pm 0,7$ & $58,2 \pm 1,5$ & 0,90 & 75,12 & 8,72 \\
\hline HAp S2/Sr & $26,9 \pm 0,3$ & $22 \pm 5$ & 1,25 & 76,87 & 9,64 \\
\hline
\end{tabular}




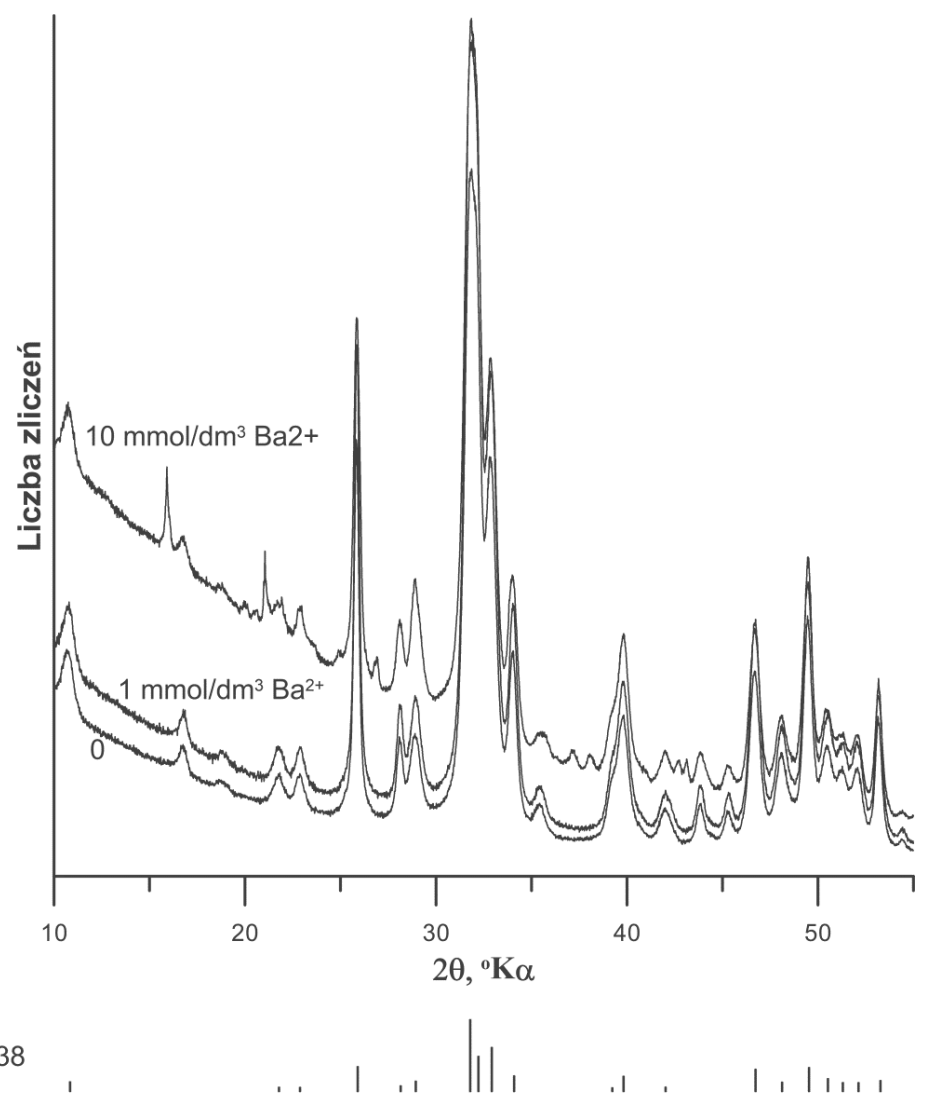

Rysunek 11. Dyfraktogram próbek HAp w roztworach: $1 \mathrm{mmol} / \mathrm{dm}^{3} \mathrm{NaCl}$, w roztworze $1 \mathrm{mmol} / \mathrm{dm}^{3} \mathrm{NaCl}$ $+1 \mathrm{mmol} / \mathrm{dm}^{3}$ jonów $\mathrm{Ba}^{2+} \mathrm{i}$ w roztworze $1 \mathrm{mmol} / \mathrm{dm}^{3} \mathrm{NaCl}+10 \mathrm{mmol} / \mathrm{dm}^{3}$ jonów $\mathrm{Ba}^{2+}$

Figure 11. PXRD of HAp samples in solutions: $1 \mathrm{mmol} / \mathrm{dm}^{3} \mathrm{NaCl}$, in $1 \mathrm{mmol} / \mathrm{dm}^{3} \mathrm{NaCl}+0.001 \mathrm{~mol} / \mathrm{dm}^{3}$ $\mathrm{Ba}^{2+}$ ions and in $1 \mathrm{mmol} / \mathrm{dm}^{3} \mathrm{NaCl}+10 \mathrm{~mol} / \mathrm{dm}^{3} \mathrm{Ba}^{2+}$ ions

\section{UWAGI KOŃCOWE}

Przebieg kinetyki procesu adsorpcji jonów metali dwuwartościowych z roztworu o stężeniu wyższym niż $1 \mathrm{mmol} / \mathrm{dm}^{3}$ wskazuje, że na początku adsorpcja przebiega szybko wyniku reakcji z grupami powierzchniowymi hydroskyapatytu lub/i wymiany kationów dwuwartościowych $\mathrm{z}$ jonami wapnia na powierzchni hydrokayapatytu, po czym następuje powolny proces adsorpcji spowodowany dyfuzją kationów w kanałach sieci krystalicznej hydroksyapatytu lub/i procesami rozpuszczania hydroksyapatutu i postawania nowej fazy. Taką kinetykę adsorpcji najlepiej opisuje równanie multieksponencjalne. 
Analiza adsorpcji wybranych kationów dwuwartościowych $\left(\mathrm{Cd}^{2+}, \mathrm{Zn}^{2+}, \mathrm{Co}^{2+}\right.$, i $\left.\mathrm{Fe}^{2+}, \mathrm{Sr}^{2+}, \mathrm{Ba}^{2+}\right)$ w funkcji $\mathrm{pH}$ potwierdza, że adsorpcja kationów zachodzi na skutek wymiany jonowej z jonami wapnia w sieci krystalicznej oraz jonami wodoru w grupach powierzchniowych hydroksyapatytu. Adsorpcja jonów $\mathrm{Co}^{2+} \mathrm{i}_{\mathrm{Cd}^{2+}}$ powoduje wzrost potencjału elektrokinetycznego, a dla roztworu o wyższym stężeniu początkowym kationów przy $\mathrm{pH} \sim 8$ obserwuje się odwrócenie ładunku na skutek przeładowania warstwy zwartej podwójnej warstwy elektrycznej na granicy hydroksyapatyt/roztwór elektrolitu.

Adsorpcja jonów $\mathrm{Ba}^{2+}$ na hydroksyapatycie od $1 \mathrm{mmol} / \mathrm{dm}^{3}$ prowadzi do obniżenia bezwzględnej wartości potencjału zeta, co prowadzi do agregacji cząstek.

Adsorpcja dwuwartościowych kationów z roztworu o początkowym stężeniu $1 \mathrm{mmol} / \mathrm{dm}^{3}$ powoduje niewielkie zmiany parametrów kryształów, wielkości kryształów i stopnia krystalicznego hydroksyapatytu. Natomiast $w$ przypadku stężenia początkowego $0.01 \mathrm{~mol} / \mathrm{dm}^{3}$ jonów $\mathrm{Ba}^{2+} \mathrm{w}$ układzie hydroksyapatyt roztwór elektrolitu w dyfraktogramie XRD obserwuje refleksy świadczące o powstaniu nowej fazy.

\section{PIŚMIENNICTWO CYTOWANE}

[1] A. Haider, S. Haider, S. S. Hanb and I.-K. Kang, RSC Adv.,2017,7, 7442.

[2] H. Oonishi Jr., H. Oonishi, H. Ohashi, I. Kawahara, Y. Hanaoka, R. Iwata, L.L. Hench, Clinical Applications of Hydroxyapatite in Orthopedics, Chapter 2 in Advances in Calcium Phosphate Biomaterials (B. Ben-Nissan ed.), Springer-Verlag Berlin Heidelberg 2014.

[3] M. Šupová, Ceram. Int. 2015, 41, 9203.

[4] N. Eliaz, N. Metoki,. Materials 2017, 10, 334.

[5] A. Besinis, T. De Peralta, C.J. Tredwin, R.D. Handy, ACS Nano, 2015,9 , 2255.

[6] P. Miretzky, A. Fernandez-Cirelli, Environ. Chem. Lett. 2008, 6,121.

[7] C. Fuller, J.R. Bargar, J.A. Davis, M.J. Piana, Environ. Sci. Technol. 2002, 36,158.

[8] A. Fihri, C. Len, R.S. Varma, A. Solhy, Coord. Chem. Rev. 2017, 347, 48.

[9] S.R. Anjum, V.N. Narwade, K.A. Bogle, R.S. Khairnar, Nano-Struct. Nano-Objects, 2018, 14, 98.

[10] E. Iyyappan, S.J.S. Justin, P. Wilson, A. Palaniappan, ACS Appl. Nano Mater., 2020, 3, 7761.

[11] S. Mondal, S.V. Dorozhkin, U. Pal, WIREs Nanomedicine\& Nanobiotechnology, 2018, 10, 1.

[12] S.S. Syamchand, G. Sony, Microchim Acta 2015, 182, 1567.

[13] S. Mondal, P. Manivasagan, S. Bharathiraja, M.S. Moorthy, V.T. Nguyen, H.H. Kim, S.Y. Nam, K.D. Lee, J. Oh, Nanomaterials 2017, 7, 426.

[14] V. Uskokovic, RSC Adv., 2015, 5, 36614.

[15] N. Rameshbabu, T.S. Sampath Kumar, T.G. Prabhakar, V.S. Sastry, K.V.G.K. Murty, K. Prasad Rao, J. Biomed. Mater. Res. A, 2007, 80, 581.

[16] L. Robinson, K. Salma-Ancane, L. Stipniece, B.J. Meenan, A.R. Boyd, J. Mater. Sci: Mater. Med., 2017, 28, 51.

[17] A. Priya, K. Senthilguru, T. Agarwal, S.N. Gautham Hari Narayana, S. Giri, K. Pramanik, K. Pala, I. Banerjee, RSC Adv., 2015, 5, 72515.

[18] J. Terra, E.R. Dourado, J.-G. Eon, D.E. Ellis, G. Gonzalezd, A.M. Rossia,. Phys. Chem. Chem. Phys., 2009, 11, 568. 
[19] N.L. Ignjatović, L. Mančić, M. Vuković, Z. Stojanović, M.G. Nikolić, S. Škapin, S. Jovanović, L. Veselinović, V. Uskoković, S. Lazić, S. Marković, M.M. Lazarević, D.P . Uskoković, Sci. Rep., 2019, 1,16305.

[20] A. Yasukawa, K. Gotoh, H. Tanaka, K. Kandori, Colloids Surf. A, 2012, 393, 53.

[21] A. Laghzizila, N. Elhercha, A. Bouhaoussa, G. Lorenteb, T. Coradinb, J. Livageb, Mater. Res.Bull. 2001, 36, 953.

[22] M. Wakamura, K. Kandori, T. Ishikawa, Colloids Surf., A 1998, 142, 107.

[23] R. Kramer, A.M. Morey, M. Staruch, S.L. Suib, M. Jain, J.I. Budnick, M. Wei, J. Mater. Sci., 2013, 48, 665 .

[24] Y. Li, C. Teck Nam, C. Ping Ooi, J. Phys. Conf. Ser., 2009, 187, 012024.

[25] M.E. Zilm, L. Chen, V. Sharma, A. McDannald, M. Jain, R. Ramprasada, M. Wei, Phys. Chem. Chem. Phys., 2016, 18, 16457.

[26] S. Mandjiny, K.A. Matis, A.I. Zouboulis, M. Fedoroff, J. Jeanjean, J.C. Rouchaud, N. Toulhoat, V. Potocek, C. Loos-Neskovic, P. Maireles-Torres, D. Jones, J. Mater. Sci., 1998, 33, 5433.

[27] T. Tite, A.-C. Popa, L.M. Balescu, I. M. Bogdan, I. Pasuk, J.M.F. Ferreira, G.E. Stan, Materials, 2018, 11, 2081.

[28] S. Meski, S. Ziani, H. Khireddine, S. Boudboub, S. Zaidi, J. Hazard. Mater., 2011, 186, 1007.

[29] A. Corami, S. Mignardi, V. Ferrini, J. Colloid Interface Sci., 2008, 317, 402.

[30] N.C. da Rocha, R.C. de Campos, A. M. Rossi, E.L. Moreira, A. D. F. Barbosa, G. T. Moure, Environ. Sci. Technol., 2002, 36, 1630.

[31] Y. Xu, F.W. Schwartz, S.J. Traina, Environ. Sci. Technol., 1994, 28, 1472.

[32] R.R. Sheha, J Colloid Interface Sci., 2007, 310, 18.

[33] B. Ma, W.S. Shin, S. Oh, Y.-J. Park, S.-J. Choi, Sep. Sci. Technol., 2010, 45, 453.

[34] M. Kukura, L.C. Bell, A.M. Posner, J.P. Quirk, J. Phys. Chem., 1972, 76, 900.

[35] K Skartsila, N. Spanos, J. Colloid Interface Sci., 2007, 308, 405.

[36] L. Bertinetti, A. Tampieri, E. Landi, C. Ducati, P.A. Midgley, S. Coluccia, G. Martra, J. Phys. Chem. C, 2007, 111, 4027.

[37] F.Z Saleeb, P.L. de Bruyn, J. Electroanal. Chem., 1972, 37, 99.

[38] T. Suzuki, T. Hatsushika, Y. Hayakawa, J. Chem. Soc., Faraday Trans I, 1981, 77, 1059.

[39] J. Reichert, J.G.P. Binner, J. Mat. Sci., 1996, 31, 1231.

[40] C. Moreno, T.M. Gregory, W.E. Brown, J. Res. Natl. Bur. Stand. A 72 1968, 72, 773.

[41] CRC Handbook of Chemistry and Physics, 84th Edition,( D. R. Linde Ed. ) CRC Press 2003.

[42] M. Markovic, B. O. Fowler, M. S. Tung, E. S. Lagergren, Composition and solubility product of a synthetic calcium hydroxyapatite. in mineral scale formation and inhibition (Z. Amjad Ed), Springer Science+Business, Media New York 1995.

[43] E. Skwarek, W. Janusz, Sep. Sci. Technol., 2016, 51, 11.

[44] Y. Li, D. Wang, S. Lim, JOJ Material Sci., 2017, 1, 555.

[45] X. Chen J. Wright, J.L . Conca, L.M. Peurrung, Environ. Sci. Technol., 1997, 98, 624.

[46] W. Janusz, E. Skwarek, Physicochem. Probl. Miner. Process, 2018, 54, 31.

[47] W. Janusz, E. Skwarek, Adsorption, 2016, $22,697$.

[48] E. Skwarek, W. Janusz, Adsorption, 2019, 25, 279.

[49] I. Smiciklas, A. Onjia, S. Raicevic, Đ. Janackovic, M. Mitric, J. Hazard. Mater. 2008, 152, 876.

[50] Y. Hashimoto, T. Sato, Chemosphere, 2007, 69, 1775.

[51] A. Bigi, M. Gandolfi, M. Gazzano, A. Ripamonti, N. Roveri, S.A. Thomas, J. Chem. Soc. Dalton Trans., 1991, 11, 2883.

[52] S. Sugiyama, N. Fukuda, H. Matsumoto, H. Hayashi, N. Shigemoto, Y. Hiraga, J.B. Moffat, J. Colloid Interface Sci., 1999, 220, 324.

[53] L. Shashkva, A.I. Ratko, N. V. Kitikova, Colloids Surf. A, 1999, 160, 207.

[54] M. Akao, H. Akoi, K. Kato, J. Mater. Sci., 1981, 16, 809. 
[55] E.V. Vysotskaya, Yu.I. Tarasevich, G.M. Klimova, L.N. Kuz’menko, Khim. Tekhnol. Vody, 2002, 24, 535 .

[56] N.Y. Mostafa, Mater. Chem. Phys., 2005, 94, 333.

[57] F. Monteil Riveira, M. Fedoroff, Sorption of Inorganic Species on Apatite's from Aqueous Solutions. In; Encyclopedia of Surface and Colloid Science, Marcel Dekker Inc., New York 2004.

[58] A. Solhya, W. Amera, M. Karkourib, R. Tahirb, A. El Bouarib, A. Fihri, M. Bousminaa, M. Zahouilya, J. Mol. Cat. A: Chem., 2011, 336, 8.

[59] M.F. Elkady, M.M. Mahmoud, H.M. Abd-El-Rahmanet, J. Non-Cryst. Solids, 2011, 357, 1118.

[60] S.M. Mousa, N.S. Ammar, H.A. Ibrahim, J Saudi Chem. Soc., 2016, $20,357$.

[61] S.T. Ramesh, N. Rameshbabu, R. Gandhimathi, P.V. Nidheesh, M. Srikanth Kumar, Appl. Water Sci., 2012, 2, 187.

[62] L. Yang, W. Zhong, J. Cui, Z. Wei, W. Wei, J. Dispersion Sci.Technol., 2016, 37, 956.

[63] I. Smiciklas, S. Dimovic, I. Plecas, M. Mitric, Water Res., 2006, 40, 2267.

[64] A.W. Marczewski, Appl. Sur. Sci., 2007, 253, 5818.

[65] E. Skwarek, Sep. Sci Technol., 2014, 49, 1654.

[66] Z. Benmaamar, H. Boutoumi, H. Hamitouche, H. Benmaamar, A. Benmaamar, A. Benmaamar, A. Aggoun, Port. Electrochim. Acta, 2019, 37, 93.

[67] Z.Y. Li, W.M. Lam, C. Yang, B. Xu, G.X. Ni, S.A. Abbah, K.M.C. Cheung, K.D.K. Luk, W.W. Lu, Biomaterials 2007, 28, 1452.

[68] X. Pan, J. Wang, D. Zhang, Desalination, 2009, 249, 609.

[69] C. Stötzel, F.A. Müller, F. Reinert, F. Niederdraenk, J.E. Barralet, U. Gbureck, Colloids Surf. B, 2009, 74, 91.

[70] M. Ferrari, L. Lutterotti, J. Appl. Phys., 1994, 76, 7246.

[71] M.E. Fleet, X. Liu, P.L. King, Am. Mineral., 2004, 89, 1422.

[72] G.C. Koumoulidis, A.P. Katsoulidis, A.K. Ladavos, P.J. Pomonis, C.C. Trapalis, A.T. Sdoukos, T.C. Vaimakis, J. Colloid Interface Sci., 2003, 259, 254.

[73] E. Landi, A. Tampieri, G. Celotti, S. Sprio, J. Eur. Ceram. Soc., 2000, $20,2377$.

[74] A. Person, H. Bocherens, J.F. Saliege F. Paris, V. Zeitoun, M. Gerard. J. Archaeol. Sci., 1995, 22, 211.

Praca wpłynęła do Redakcji 19 kwietnia 2021 r. 